*akls View/Frint Document Cover Sheet tow

This document was retrieved from the Boeing ISEARCH System.

Accession \#: D196054842

Document \#: SD-WM-ER-459

Title/Desc:

TANK 241C102 HEADSPACE GAS \& VAPOR CHARACTERIZATION RESAULTS FOR SAMPLES COLLECTED IN 8/1994 
Page 1 of $Z$. Proj.

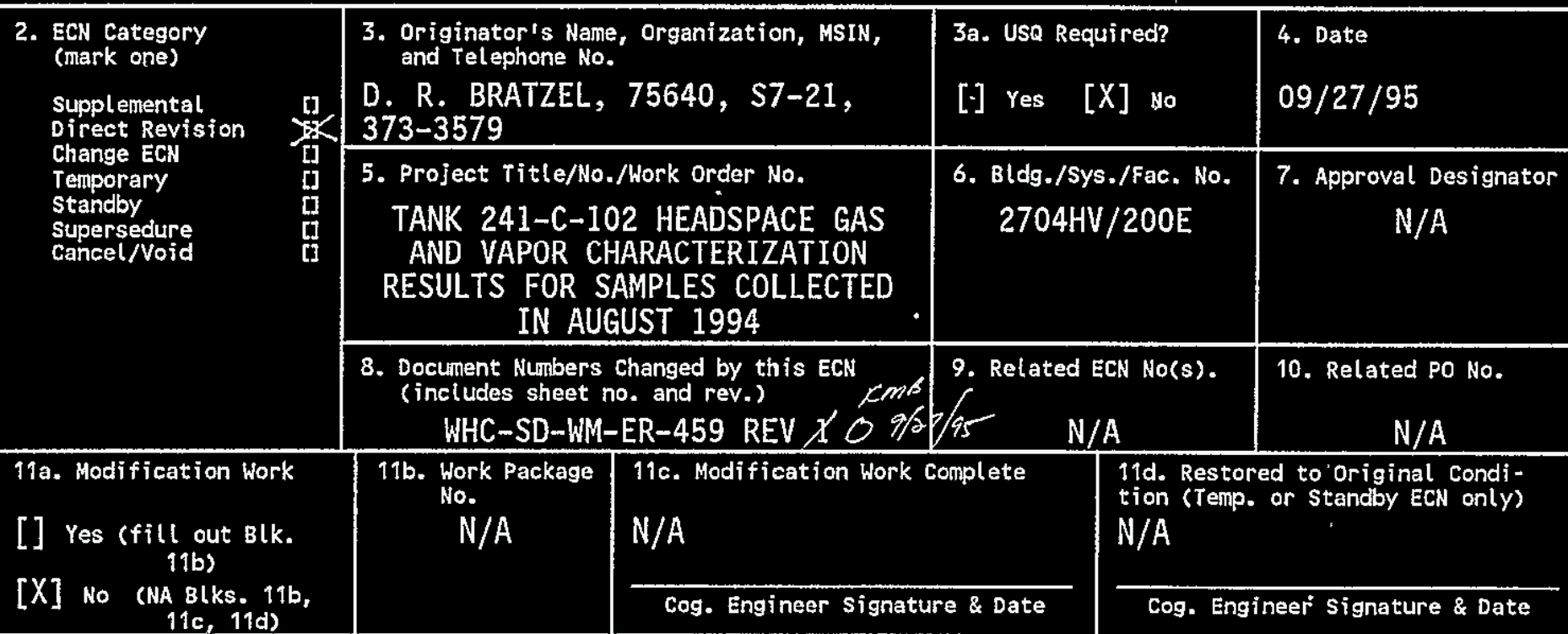

12. Description of change

Title change and complete rewrite.

13a. Justification (mark one)

Criteria Change [X] Design Improvement [] Environmental [] Facility Deactivation

As-Found [] Facilitate Const [] Const. Error/Omission [] Design Error/Omission

13b. Justification Detal ls

Complete rewrite which includes all vapor sampling events to date and data qualification.

14. Distribution (include name, MSIN, and no. of copies)

See attached Distribution Sheet

RELEASE STAMP

OFFICIAL RELEASE BY WHC

DATE SEP 281995

$5+214$ 


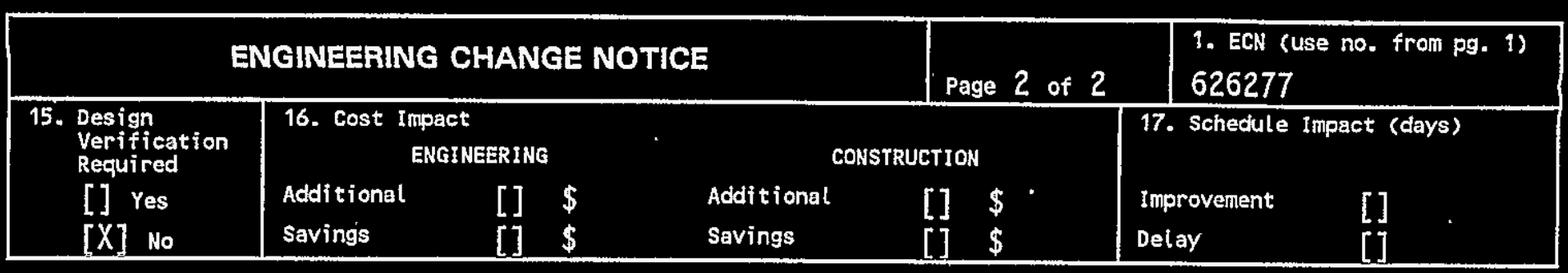

18. Change Impact Review: Indicate the related documents (other than the engineering documents identified on side 1 ) that will be affected by the change described in Block 12 . Enter the affected document number in Block 19. SDD/DD

Functional Design Criteria

[] Solsmic/Stress Arialysis

- []

[]

$\begin{array}{ll}\text { [] } & \text { Stress/Dosign Roport } \\ \text { [ ] } & \text { Interface Control Drawing }\end{array}$

Operating Specification

Criticality Specification

Concoptual Design Report

[] Calibration Procedure

[]

installation Procedure

[]

[]

[]

Maintenancẹ Proceduro

Const. Spec.

[]

Engineering Procedure

[]

Procurement Spec.

Vendor Information

OM Manual

[]

Operating instruction

[]

[] Operating Procodure

FSAR/SAR

[]

Safety Equipment List

Radiation Work Permit

[]

Operational Safoty Requirement

IEFD Drawing

[]

[]

Environmental Impact Statement

[]

Environmental Report

[]

Environmental Permit

[]

Cell Arrangement Drawing

Essential Material Specification

Fac. Proc. Samp. Schedule

Tank Calibration Manual

Health Physics Procedurs

Spares Multiple Unit Listing

Test Procedures/Specification

Component Index

ASME Coded item

Human Factor Consideration

Computer Software

[]

[]

[]

Electric Cireuit Schedula

ICRS Proceduro

[]

Process Control Manual/Plan

[]

Process Flow Chart

[] Purchase Requisition

Tickler File

inspection Plan

[]

Inventory Adjustment Request

[] .

19. Other Affected Documents: (NOTE: Documents listed below will not be revised by this ECN.) Signatures below indicate that the signing organization has been notified of other affected documents listed below. Document Number/Revision

20. Approvals

\section{signature}

QPERATIONS AND ENGLWEERING

Cog. Eng. D. R. Bratzel DEB

Cog. Mgr. T. J. Kelley

QA

Safety

Environ.

Other

Proj.

Proj.

Proj.

Proj.

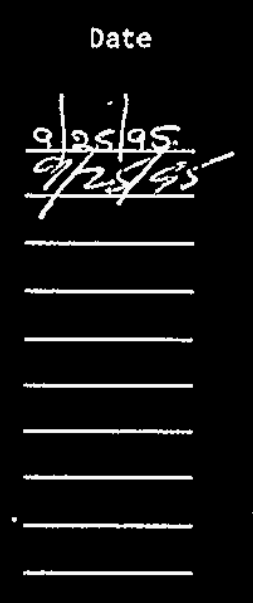

ARCHLTECT - ENGINEER

PE

QA

Safety

Design

Environ.

other

DEPARTMENT OF ENEROY

Signature or a Control Number that

tracks the Approval signature

ADDITIONAL
Date
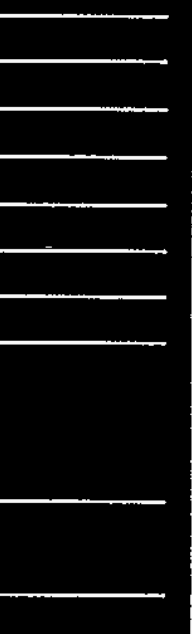


\section{RELEASE AUTHORIZATION}

Document Number: WHC-SD-WM-ER-459, REV 1

Tank 241-C-102 Headspace Gas and Vapor

Document Title: Characterization Results for. Samples Collected in August 1994

Release Date: $\quad 9 / 27 / 95$

This document was reviewed following the procedures described in WHC-CM-3-4 and is:

APPROVED FOR PUBLIC RELEASE

WHC Information Release Administration Specialist:
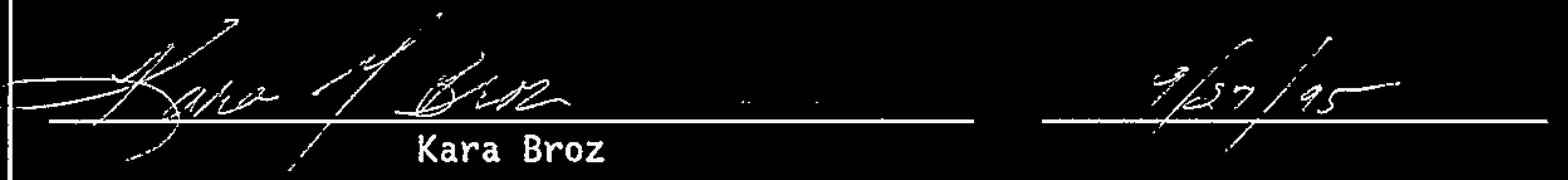

TRADEMARK DISCLAIMER. Reference herein to any specific commercial product, process, or service by trade name, trademark, manufacturer, or otherwise, does not necessarily constitute or imply its endorsement, recommendation; or favoring by the United States Government or any agency thereof or its contractors or subcontractors.

This report has been reproduced from the best available copy. Available in paper copy. Printed in the United States of America. To obtain copies of this report, contact:

Westinghouse Hanford Company - Document Control Services

P.0. Box 1970, Mailstop H6-08, Richland, WA 99352

Telephone: (509) 372-2420; Fax: (509) 376-4989 
THIS PAGE INTENTIONALLY

LEFT BLANK 


2. Title
TANK 241-C-102 HEADSPACE GAS AND VAPOR
CHARACTERIZATION RESULTS FOR SAMPLES COLLECTED IN
AUGUST 1994

5. Key Words

CHARACTERIZATION OBJECTIVES, TANK HEADSPACE, SAMPLING EVENT, INORGANIC GASES, ORGANIC VAPORS

\section{Number}

WHC-SD-WW-ER-459
4. Rev No.

6. Author

Name: D. R. BRATZEL

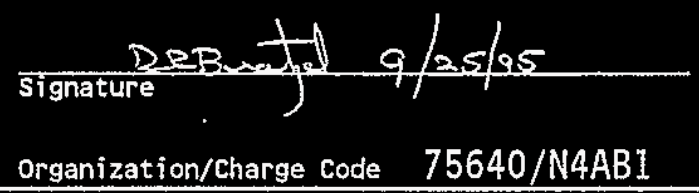

\section{Abstract}

Significant changes have been made to all of the original vapor characterization reports. This report documents specific headspace gas and vapor characterization results for all vapor sampling events to date. In addition, changes have been made to the original vapor reports to qualify the data based on quality assurance issues associated with the performing laboratories. 
THIS PAGE INTENTIONALLY

LBFT BLANK 


\begin{tabular}{|c|c|c|c|}
\hline & RECORD OF REVISION & $\begin{array}{l}\text { (1) Document Number } \\
\text { WHC-SD-WM-ER-45 }\end{array}$ & Page 1 \\
\hline $\begin{array}{l}\text { (2) Title } \\
\text { TANK } 241-C- \\
\text { IN AUGUST } 1\end{array}$ & $\begin{array}{l}102 \text { HEADSPACE GAS AND VAPOR CHARACTERIZATION } \\
994\end{array}$ & ILTS FOR SAMPL & ECTED \\
\hline (3) Pavicion & CHANGE CONTROLL RECORD & Authorized ff: & \\
\hline 0 & $\begin{array}{l}\text { (7) WHC-SD-WM-ER-459, REV. 0, EDT } 612346 \\
\text { May } 31,1995\end{array}$ & $\begin{array}{ll}\text { (5) Cog. Engr. } & \text { (6) } \\
\end{array}$ & Mgr. Date \\
\hline 1 RS & $\begin{array}{l}\text { Complete revision and title change: ECN } \\
626277\end{array}$ & RBsald & $=$ \\
\hline & & & 2 \\
\hline & & & \\
\hline & & & \\
\hline & & & \\
\hline & & & \\
\hline & & & \\
\hline & & & \\
\hline & & & \\
\hline & & & \\
\hline & & & \\
\hline
\end{tabular}


THIS PAGE INTENTIONALLY LENT BLANK 


\title{
Tank 241-C-102 Headspace Gas and Vapor Characterization Results for Samples Collected in August 1994
}

\author{
J. L. Huckaby \\ Pacific Northwest Laboratories \\ D. R. Bratzel \\ Westinghouse Hanford Company
}

Date Published

September 1995

Prepared for the U.S. Department of Energy

Office of Environmental Restoration and

Waste Management

$\begin{array}{ll}\text { Westinghouse } & \text { P.O Box } 1970 \\ \text { Hanford Company } & \text { Richland, Washington }\end{array}$

Management and Operations Contractor for the

U.S. Department of Energy under Contract DE.ACO6.87FL 10930 


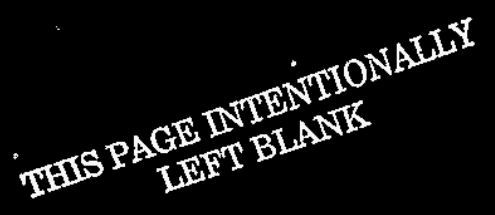


WHC-SD-WM-ER-459 Rev.1

Tank 241-C-102 Headspace Gas and Vapor Characterization Results

for Samples Collected in August 1994

September 22, 1995

\author{
J. L. Huckaby \\ Multimedia Exposure Assessment. \\ Pacific Northwest Laboratories \\ D. R. Bratzel \\ Tank Waste Characterization Program \\ Westinghouse Hanford Company
}




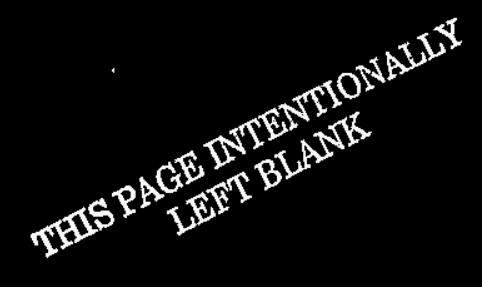


WHC-SD-WM-ER-459 ReV.1

\section{Contents}

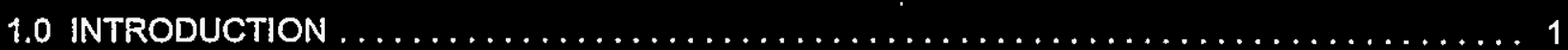

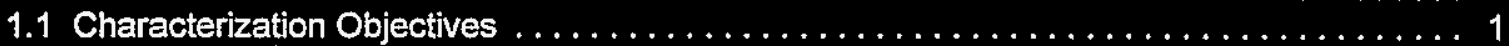

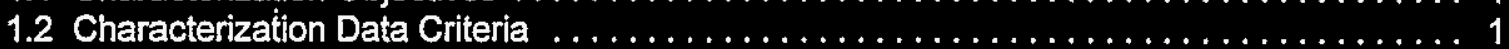

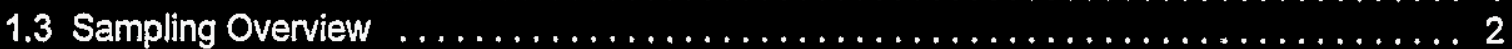

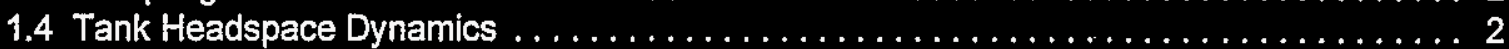

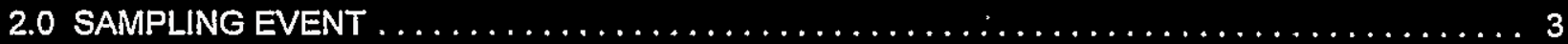

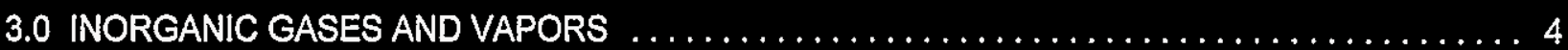

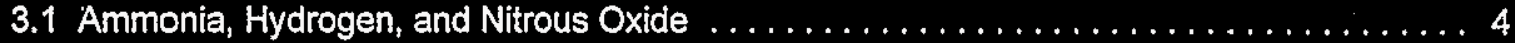

3.2 Carbon Monoxide and Carbon Dioxide $\ldots \ldots \ldots \ldots \ldots \ldots \ldots \ldots \ldots \ldots \ldots \ldots \ldots$

3.3 Nitric Oxide, Nitrogen Dioxide, Water and Tritium $\ldots \ldots \ldots \ldots \ldots \ldots \ldots \ldots \ldots \ldots \ldots$

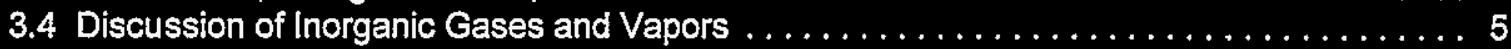

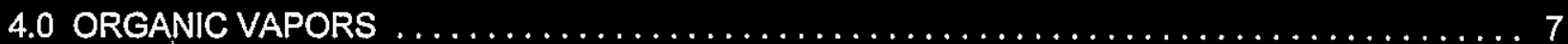

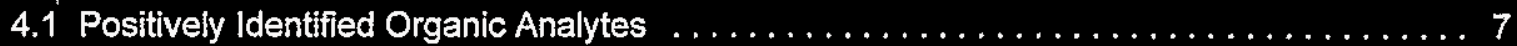

4.2 Tentatively Identified Organic Analytes $\ldots \ldots \ldots \ldots \ldots \ldots \ldots \ldots \ldots \ldots \ldots \ldots$

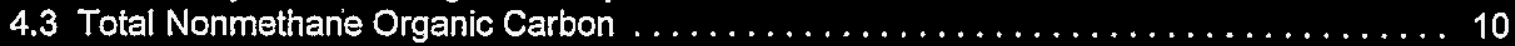

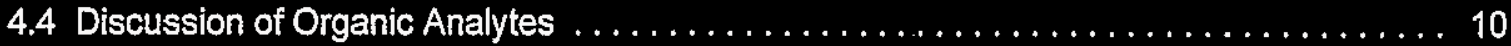

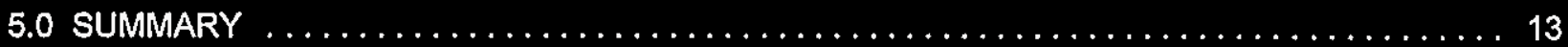

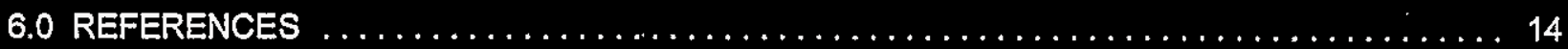

Acronyms and Abbreviations

CES

EPA

GC

GC/MS

LFL

MS

NFPA

NPH

OGIST

ORNL

PNL

ppmv

TNMOC

TST

vol\%

VSS

WHC consensus exposure standard

Environmental Protection Agency

gas chromatograph

gas chromatograph/mass spectrometer

lower flammability limit

mass spectrometer

National Fire Protection Association

normal paraffinic hydrocarbon

Oregon Graduate Institute of Science and Technology

Oak Ridge National Laboratory

Pacific Northwest Laboratory

parts per million by volume, $1 \mathrm{ppmv}=10^{-4} \mathrm{vol} \%$

total nonmethane organic carbon

triple sorbent trap

percent by volume, 1 vol $\%=10,000$ ppmv

vapor sampling system

Westinghouse Hanford Company 


\section{WHC-SD-WM-ER-459 Rev.1}

\section{Acknowledgements}

The authors wish to thank Chris Simonen for her work verifying data and generating tables, and Shas Mattigod for his help with the construction and reviews of this document. The authors also wish to thank Luther Buckley, Clarence Homi, and Tom Kunthara for their contributions to the final reviews and publication of this document. 
WHC-SD-WM-ER-459 Rev.1

Tank 241-C-102 Headspace Gas and Vapor Characterization Results

for Samples Collected in August 1994

\subsection{INTRODUCTION}

\subsection{Characterization Objectives}

Tank C-102 headspace gas and vapor samples were collected and analyzed to help determine the potential risks of fugitive emissions to tank farm workers. The drivers and objectives of waste tank headspace sampling and analysis are discussed in Program Plan for the Resolution of Tank Vapor /ssues (Osborne and Huckaby 1994). Tank C-102 was vapor sampled in accordance with Data Quality Objectives for Generic In-Tank Health and Safety Issue Resolution (Osborne et al. 1994). Results presented here represent the best available data on the headspace constituents of tank C-102.

\subsection{Characterization Data Criteria}

Data Quality Objectives for Generic In-Tank Health and Safety Issue Resolution describes parameters for data collection to ensure appropriate conclusions can be drawn from the data. Tank headspace characterization data were collected to help in the evaluation of 1) headspace flammability, and 2) identification and quantification of compounds of toxicological concern.

Single Shell Tank Interim Operational Safety Requirements (Dougherty 1995) specifies that combustible constituents in tank headspaces be maintained below $25 \%$ of the lower flammability limit (LFL). This essentially agrees with National Fire Protection Association requirements that combustible concentrations be maintained at or below $25 \%$ of the LFL (NFPA 1992). Current governing operating specifications for Watchlist tanks, such as tank BY-105, specify that combustible constituents be maintained at or below 20 $\%$ of the LFL (WHC 1995a).

Headspace characterization data are used by Westinghouse Hanford Company (WHC) Tank Waste Remediation Systems Industrial Hygiene as source term data in the industrial hygiene strategy to protect workers from tank fugitive emissions. Because selection of worker protective equipment must be based on industrial hygiene monitoring of the work place and not on source term data (29 CFR 1910.120), tank headspace characterization data can not be used for this purpose. Furthermore, because there are mechanisms by which headspace constituents can be either diluted or concentrated as they are released to the atmosphere, the headspace characterization data should not be considered to be representative of emissions at the point of emission.

These statements notwithstanding, the data quality objectives document specifies that the industrial hygiene group be advised if constituents with toxicological properties exceed $50 \%$ of the appropriate consensus exposure standard (CES) for non-carcinogens, or $10 \%$ of the appropriate CES for carcinogens. A CES is defined as the most stringent of known regulatory or recommended toxicological values for the workplace (Osborne et al. 1994). 
WHC-SD-WM-ER-459 Rev.1

\subsection{Sampling Overview}

Tank C-102 headspace characterization data presented here are from a single sampling event. Samples collected are thought to have been representative of the tank headspace when the tank was sampled (Meacham et al. 1995), and sample analyses were designed to provide a reasonabiy accurate and complete characterization of the significant headspace constituents. No assessment has been made of how the tank C-102 headspace composition changes with time, though studies of tank C-103 suggest that composition changes probably occur very slowly in passively ventilated tanks, such as tank C-102 (Huckaby and Story 1994).

\subsection{Tank Headspace Dynamics}

Tank C-102 is the second tank in a 3-tank cascade with tanks C-101 and C-103 and is connected to tank C-101 via a 7.4-cm (2.9-in.) inside diameter, 7.6-m (25-ft) long cascade line. Tanks C-101 and C-103 are connected by a similar cascade line. Since these cascade lines connect the headspaces of these tanks, gases and vapors originating from the wastes in tank C-101 or tank C-103 may be transferred to tank C102 (unless the cascade lines are obstructed).

Barometric pressure typically rises and falls on a diurnal cycle, with an average daily exchange of air equal to about $0.46 \%$ of each tank headspace (Huckaby 1994). When headspace samples were collected from these tanks, tanks $\mathrm{C}-101$ and $\mathrm{C}-103$ also received small streams of dry ambient air to protect waste surface level instruments from condensation of water vapor. The flowrate of this instrument air varied from about 1.4 to $1.7 \mathrm{~m}^{3} / \mathrm{hr}$ (50 to $60 \mathrm{ft}^{3} / \mathrm{hr}$ ), (Huckaby 1994).

The breather riser on tank C-101 was valved shut in December 1989, so that any air exchange with the atmosphere would occur via the cascade line to tank C-102. Furthermore, since December 1989 the cascade of tanks C-101, C-102, and C-103 has had only 1 breather riser open (either on tank C-102 or tank C-103). In the period before headspace samples were collected from tank C-102 (specifically since March 1993), the breather riser on tank C-103 had been valved shut, and the intended pathway for tanks $\mathrm{C}-101, \mathrm{C}-102$, and $\mathrm{C}-103$ to breathe with the atmosphere was via the breather riser on tank C-102 (Conrad 1994).

Anderson (1990) notes, however, that the cascade line between tanks C-101 and C-102 was partially plugged in 1954. A comparison of vapor data indicates that the cascade line between tanks C-101 and C102 does not effectively transport organic vapors, and may be blocked (Huckaby and Bratzel 1995). To determine the origin of gases and vapors in tank $\mathrm{C}-102$, it is important to understand the extent to which tanks C-101 and C-103 breathe through tank C-102, because constituents detected in the headspace of tank C-102 may actually have originated from the waste in tanks C-101 or C-103'. Sections 3.4 and 4.4 discuss what the available headspace data from tanks $\mathrm{C}-101, \mathrm{C}-102$, and $\mathrm{C}-103$ indicate about whether tanks $\mathrm{C}-101$ and $\mathrm{C}-103$ breathe freely via their cascade lines with tank $\mathrm{C}-102$.

\footnotetext{
1 Tank C-103 is known to have a layer of semivolatile organic liquid floating on the aqueous waste (Pool and Bean 1994), and the highest total concentration of organic vapors of any waste tank known (Huckaby and Story 1994);
} 


\subsection{SAMPLING EVENT}

Headspace gas and vapor samples were collected from tank C-102 using the vapor sampling system (VSS) on August 23, 1994 by WHC Sampling and Mobile Laboratories (WHC 1995). Sample collection and analysis were performed as directed by the sample and analysis pian ${ }^{2}$ (WHC 1995, Appendix A). The tank headspace temperature was determined to be $25.8{ }^{\circ} \mathrm{C}$. Air from the $\mathrm{C}-102$ headspace was withdrawn via a $6.1-\mathrm{m}$ long heated sampling probe mounted in riser 3 , and transferred via heated tubing to the VSS sampling manifold. Heated zones of the VSS were maintained at approximately $50^{\circ} \mathrm{C}$. All samples were collected between 12:46 p.m. and 4:20 p.m., with no anomalies noted.

Sampling media were prepared and analyzed by WHC, Oak Ridge National Laboratories (ORNL), Pacific Northwest Laboratories (PNL), and Oregon Graduate Institute of Science and Technology (OGIST) through a contract with Sandia National Laboratories. The 39 tank air samples and 2 ambient air control samples collected are listed in Table $2-1$ by analytical laboratory. Table $2-1$ also lists the 14 trip blanks and 2 field blanks provided by the laboratories.

A general description of vapor sampling and sample analysis methods is given by Huckaby et al. (1995). The sampling equipment, sample collection sequence, sorbent trap sample air flow rates and flow times, chain of custody information, and a discussion of the sampling event itself are given in WHC (1995b).

2 The current requirement that sampling and analysis parameters be specified by a tank characterization plan was not in effect for gas and vapor sampling until October 1, 1994. 


\subsection{INORGANIC GASES AND VAPORS}

Analytical results of sorbent trap and SUMMA ${ }^{\mathrm{TM}, 3}$ canister tank air samples for selected inorganic gases and vapors are given in Table 3-1 in parts per million by volume (ppmv) in dry air. The concentration of water vapor given in Table 3-1 has been adjusted to tank conditions as given in Section 3.3. Inorganic analyte sorbent traps were prepared and analyzed by PNL (Klinger et al. 1995a), and SUMMA ${ }^{\text {TM }}$ canisters were analyzed for inorganic analytes by OGIST (Rasmussen 1994a).

PNL analyses sorbent traps for inorganic compounds were performed 26 days after sample collection (Ligotke 1995), and analyses of SUMMA ${ }^{\text {TM }}$ canisters were started by OGIST 21 days after the sample collection (Rasmussen 1994a). These analyses were conducted within the allowed 60-day holding time specified by the WHC quality assurance project plan (Keller 1994). The 60-day holding time was administratively chosen, and no holding time study has been performed to address the stability of compounds in SUMMA ${ }^{\text {TM }}$ canisters in the chemical matrix of the waste tank samples.

PNL results were produced at PNL quality assurance impact level 3. OGIST did not have a WHCapproved quality assurance project plan in place when performing analyses, so OGIST data have been placed in square brackets both in Table 3-1 and elsewhere in this report to indicate that they represent secondary results.

\subsection{Ammonia, Hydrogen, and Nitrous Oxide}

The ammonia concentration in C-102 headspace was determined to be $189 \mathrm{ppmv}$. Ammonia has been observed in vitually all of the waste tanks sampled to date, at concentrations ranging from about 3 ppmv in tank C-108 (Lucke et al. 1995a), to 1040 ppmv in BY-108 (McVeety et al. 1995). Given the LFL of ammonia in air is about $15 \%$ by volume (vol\%), the measured 189 ppmv corresponds to about $0.13 \%$ of the LFL, and does not contribute appreciably to the flammability of the headspace.

The concentration of hydrogen in tank C-102 was determined to be [133 ppmv]. Hydrogen in the waste tanks is of concern as a fuel. Given that the LFL for hydrogen in air is about 4 vol\%, the $133 \mathrm{ppmv}$ hydrogen concentration in tank C-102 corresponds to about $0.3 \%$ of its LFL. At this level hydrogen is not a flammability concern in tank C-102.

The nitrous oxide concentration in tank C-102 was measured at [154 ppmv]. Nitrous oxide has been detected in other waste tanks at concentrations as low as about 12 ppmv in tank TX-105 (Klinger et al. 1995b), and as high as about 868 ppmv in tank U-103 (Ligotke et al. 1995). Under the proper conditions, nitrous oxide can serve as an oxidizer to support combustion. However, Cashdollar et al. (1992) found that nitrous oxide had no significant effect on the flammability of hydrogen and air mixtures for hydrogen concentrations less than $20 \mathrm{vol} \%$, and that "small amounts of nitrous oxide (relative to air) do not appear to have much effect on the flammability". Their results suggest the measured nitrous oxide concentration is much too low to have a significant effect on the fiammability of the tank C-102 headspace.

${ }^{3}$ SUMMA is a trademark of Molectrics, Inc., Cleveland, Ohio. 
WHC-SD-WM-ER-459 Rev.1

\subsection{Carbon Monoxide and Carbon Dioxide}

Carbon monoxide, measured to be [ 4.0 ppmV] in SUMMA ${ }^{\mathrm{TM}}$ samples, is at a much higher concentration in tank C-102 than it is in ambient air, where it typically ranges from 0.05 to $0.15 \mathrm{ppmv}$. Because different analytical methods have been used to measure carbon monoxide in the waste tanks sampled to date, the information on carbon monoxide has varied from tank to tank. Elevated waste tank headspace carbon monoxide concentrations are common, and are thought to be due to the decomposition of organic waste in the tanks. The [4.0 ppmv] of carbon monoxide in tank C-102 is the third highest measured in any waste tank to date; tanks C-103 and C-101 were determined to have [26.7 ppmv] and [15.5 ppmv], respectively, of carbon monoxide (Rasmussen and Einfeld 1994, Rasmussen 1994b).

The average carbon dioxide concentration in the tank C-102 headspace, [8.2 ppmv], is among the lowest measured in any waste tank to date. Normally present in the ambient air at a concentration of 350 to 400 ppmv, carbon dioxide is typically at a lower concentration in the waste tank headspaces than in ambient air. Carbon dioxide introduced by air exchange with the atmosphere is readily absorbed by caustic supernatant and interstitial liquids of the waste tanks, and converted to carbonate in solution.

\subsection{Nitric Oxide, Nitrogen Dioxide, Water and Tritium}

Nitric oxide and nitrogen dioxide concentrations in the tank C-102 headspace were determined to be 0.24 ppmv and $\leq 0.05$ ppmv, respectively. These are both acid gases that would have very low equilibrium concentrations above the high $\mathrm{pH}$ sludge in tank $\mathrm{C}-102$. The measurable presence of nitric oxide may be due to its formation from oxygen and nitrogen in the radiation field of the headspace. These constituents could potentially serve as oxidizers to support combustion, but at the measured concentrations would have a negligible effect on the flammability of the tank C-102 headspace.

The water vapor concentration of tank C-102 was determined to be about $20.4 \mathrm{mg} / \mathrm{L}$, at the tank headspace temperature of $25.8^{\circ} \mathrm{C}$ and pressure of 990 mbar (742.7 torr), (WHC 1995). This corresponds to a water vapor partial pressure of $28.1 \mathrm{mbar}\left(21.1\right.$ torr), to a dew point of $23.0^{\circ} \mathrm{C}$, and to a relative humidity of $85 \%$.

Silica gel sorbent traps were used to sample for tritium. It is assumed that tritium produced by the waste combines with hydroxide ions to form tritium-substituted water. Evaporation of the tritium-substituted water would then result in airborne radioactive contamination. Silica gel sorbent traps adsorb virtually all (normal and tritium-substituted) water vapor from the sampled tank air, and are analyzed at the WHC 222. $S$ laboratory. Radiochemical analysis of the silica gel trap indicated the total activity of the headspace to be less than 50 pCilL (WHC 1995).

\subsection{Discussion of Inorganic Gases and Vapors}

Aside from water vapor, the most abundant waste constituents in the tank $\mathrm{C}-102$ headspace are ammonia, nitrous oxide, and hydrogen. These have been detected in most tank headspaces sampled to date, and are usually the dominate waste species.

The relative standard deviakions of the inorganic gas and vapor results given in the last column in Table 31 are good. Relative standard deviations range from $1 \%$ for nitrous oxide, to $17 \%$ for nitric oxide results. The precision reported depends both on sampling parameters (e.g., sample flow rate and flow time for 


\section{WHC-SD-WM-ER-459 ReV.1}

sorbent traps) and analytical parameters (e.g., sample preparation, dilutions, etc.), and the small relative standard deviations suggest good control was maintained both in the field and in the laboratories.

Table 3-2 lists, for comparison, selected sampling data and inorganic gas and vapor concentrations measured in tanks $\mathrm{C}-101, \mathrm{C}-102$, and $\mathrm{C}-103$. The inorganic gases and vapors in these tanks are at concentrations that support the premise that tanks C-101 and C-103 breathe primarily via their cascade lines with tank $\mathrm{C}-102$. To understand this, suppose that tank $\mathrm{C}-101$ did breathe only via its cascade line to tank C-102 (as per the ventilation configuration). Then all the air inhaled by tank C-101 would have the composition of air in tank C-102, so that at steady state (neglecting any losses of constituents in transit), every headspace constituent in tank $\mathrm{C}-102$ would be present in tank $\mathrm{C}-101$ at a concentration at least as high as it is in tank C-102. Furthermore, any gases or vapors generated or released by the waste in tank C-101 would raise the concentration of these constikuents in tank C-101 above the level in tank C-102. As indicated in Table 3-2, the concentrations of hydrogen, carbon dioxide, carbon monoxide, nitric oxide, and nitrous oxide are all significantly higher in tank C-101 than they are in tank C-102. Likewise, the concentrations of these same constituents, as well as ammonia, are higher in tank C-103 than in tank C102.

Amongst the inorganic analytes, listed in Table 3-2, only ammonia is at a higher concentration in tank C102 than it is in tank C-101. This exceptional relationship of ammonia, if indeed tank C-101 breathed primarily via the cascade line with tank $\mathrm{C}-102$, may be reasonable given its solubility in water. Aqueous condensate forming in the cascade line (the dewpoint of tank $\mathrm{C}-101$ is about $30^{\circ} \mathrm{C}$, Huckaby and Bratzel 1995) might absorb enough of the ammonia vapor in transit to tank $\mathrm{C}-101$ to cause this constituent to be lower in tank C-101 than in tank C-102.

Though the data from tanks C-101, C-102, and C-103 (with special allowance for ammonia in tank C-101) are consistent with the premise that tanks $\mathrm{C}-101$ and $\mathrm{C}-103$ breathe primarily via their cascade lines with tank C-102, the data do not prove that this is happening. The selected gas and vapor concentrations may be higher in tanks $\mathrm{C}-101$ and $\mathrm{C}-103$ than in tank $\mathrm{C}-102$ simply because their generation rates are higher in those tanks. 
WHC-SD-WM-ER-459 Rev.1

\subsection{ORGANIC VAPORS}

Organic vapors in the tank C-102 headspace were sampled using SUMMA ${ }^{\mathrm{TM}}$ canisters, which were analyzed by OCIST and PNL, and triple sorbent traps (TSTS), which were anaiyzed by ORNL. ORNL and PNL. used gas chromatographs (GCs) equipped with mass spectrometer (MS) detectors to separate, identify, and quantitate the analytes. A quantitative measurement of the total organic vapor concentration by the U.S. Environmental Protection Agency (EPA) task order 12 (TO-12) method was also performed by OCIST (EPA 1988, Rasmussen 1994a). Descriptions of sample device cleaning, sample preparations, and analyses are given by Jenkins et al. (1995a), Rasmussen (1994a), and Klinger et al. (1995a).

PNL SUMMATM sample results should be considered to be the primary organic vapor data for tank C-102: PNL results were produced at PNL quality assurance impact level 3 . Because tank $\mathrm{C}-102$ analyses were initially assigned low priority by WHC, PNL SUMMA ${ }^{\text {TM }}$ canister analyses for organic vapors were not performed until 222 days after sample collection (Ligotke 1995), greatly exceeding the specified 60-day holding time (Keller 1994). The 60-day holding time was administratively chosen, because no holding time study has been performed to address the stability of organic compounds in SUMMA ${ }^{\mathrm{TM}}$ canisters in the likely chemical matrix of the waste tanks.

ORNL analyses of TST samples from this and other waste tanks generally agree with, support, and augment the SUMMA ${ }^{T M}$ sample results. However, because certain WHC quality assurance requirements -were not satisfied by ORNL, the quality assurance assessment of ORNL by Hendrickson (1995) should be reviewed before results unique to the TST samples are used for decision making.

All TSTs prepared by ORNL had 3 surrogate compounds added to evaiuate sample matrix effects, potential handling, storage, and shipment problems, and analytical instrumentation performance (Jenkins et al. 1995a). ORNL evaluated the surrogate recoveries using a statistical approach similar to that prescribed by SW 846 Method 8260 A Volatile Organic Compounds by Gas Chromatography/Mass Spectrometry (GC/MS) Capillary Column Technique (EPA 1992). Using this approach, ORNL reported that all surrogates had standard deviation values within the $95 \%$ contidence interval for variance, indicating that no bias was introduced in the measurement of analyte quantities (Jenkins 1995a).

\subsection{Positively Identified Organic Analytes}

Positive identification of organic analytes using the methods employed by PNL and ORNL involves matching the GC retention times and MS data from a sample with that obtained from the analysis of standards. The concentration of an analyte in the sample is said to be quantitatively measured if the response of the GCMS has been established at several known concentrations of that analyte (i.e., the CCMS has been calibrated for that analyte), and the MS response to the analyte in the sample is between the lowest and highest responses to the known concentrations (i.e., the analyte is within the calibration range).

ORNL and PNL were assigned different lists of organic compounds, or target analytes, to positively identify and measure quantitatively. The ORNL target analyte list was derived from a review of the tank C103 headspace constituents by a panel of toxicology experts (Mahlum et al. 1994). The PNL target analyte list included 39 compounds of the EPA task order 14 (TO-14) method, which are primarily halocarbons and common industrial solvents (EPA 1988), plus 14 analytes selected mainly from the toxicology panel's review of tank C-103. 


\section{WHC-SD-WM-ER-459 Rev.1}

Table 4-1 lists the organic compounds positively identified and quantitated in SUMMA ${ }^{T M}$ samples. Analysis for methane was performed by OGIST (Rasmussen 1994a), other SUMMA ${ }^{\text {TM }}$ analyses were performed according to the EPA TO-14 methodology by PNL (EPA 1988, Klinger et al. 1995a). Only 2 of the 39 TO-14 target analytes (i.e., toluene and trichlorofluoromethane), but all 14 of the additional target analytés were above the 0.005 ppmv quantitation limit of the analyses. Averages reported are from analyses of 3 SUMMA ${ }^{\text {TM }}$ canister samples.

Jenkins et al. (1995a) report the positive identification of 26 of 27 target analytes in TST samples. 1,1Dichloroethene was the only TST target analyte not detected in the TST samples. The average concentrations of the positively identified compounds, from the analysis of 3 TSTs, are given in Tables 4$2,4-3$, and 4-4. Despite calibration of the instrument over about a 20-fold concentration range, 12 of the positively identified compounds were measured to be outside of the calibration range in at least 1 of the 3 TST samples. The average concentrations of the positively identified compounds are given in Tables 4-2, 4-3, and 4-4. Table 4-2 lists the positively identified, quantitated analytes, Table 4-3 lists the positively identified anaiytes which were not quantitated (because the measurement was outside the callbration range for at least 1 sample), and Table $4-4$ lists the positively identified analytes which exceeded their practical holding times. Tables $4-2,4-3$, and $4-4$ are mutually exclusive, so that no analyte appears in more than 1 of these tables. Data in Tables $4-3$ and $4-4$ may not be accurate to within $\pm 30 \%$ as specified by Burnum (1995).

The ORNL practical holding time is defined as the holding time for which there is a $15 \%$ risk that the concentration of an analyte in the sample will be below its initial concentration. As indicated in Table 4-4, butanal, 1-butanol, 2-pentanone, propanone, and n-pentanenitrile exceeded their practical holding times, and may have been affected by the 79 day period between sample collection and analysis (Jenkins 1995b). Jenkins et al. (1995b) describe the ORNL. practical holding time study, and report the practical holding times for these five compounds. It should be noted that the contractual holding time for the TST samples was 60 days.

The concentrations of tributyl phosphate and dibutyl butylphosphonate reported in Table 4-3 probably underestimate the actual concentrations in the tank headspace. These compounds have very low volatility, and are thought to be adsorbed by glass fiber filters used during sampling to protect samples from radiolytic particulates.

Both PNL and ORNL report target analyte concentrations in ppmv of anaiyte in dry air. To correct for the measured water vapor content of tank C-102 and obtain concentration in ppmv of analyte in moist tank air, multiply the dry-air ppmv concentrations by 0.972 .

Eleven target analytes were common to both TST and SUMMATM analyses. Table 4-5 lists these, and their reported average concentrations in TST and SUMMA ${ }^{\text {TM }}$ samples. Results from these 2 sampling and analytical methods are in good agreement for the nitriles (ethanenitrile, propanenitrile, and n-butanenitrile). The methods also agree reasonably well on the concentrations of propanone, $n$-heptane, and n-decane. However, as indicated in Table 4-5, the reported concentrations of dichloromethane, benzene, toluene, and $n$-hexane by the 2 methods are not in agreement. The differences in reported values are not significant except for benzene. Despite the relativeiy poor precision of the TST benzene measurements, it is advisable to assume (to be conservative) the higher benzene concentration of $0.32 \mathrm{ppmv}$ is correct.

The most abundant analytes in Tables 4-1 through 4-4 are methane, propanone, n-dodecane, ethanenitrile, $n$-tridecane, 1-butanol, and n-undecane. At the reported concentrations, the target anaiytes do not individually or collectively represent a flammability hazard. 
WHC-SD-WM-ER-459 Rev.1

\subsection{Tentatively Identified Organic Analytes}

In addition to the target analytes, the ORNL and PNL analytical procedures allow the tentative identification of other organic compounds. Tentative identification of analytes was performed by comparing the MS molecular fragmentation patterns with a library of known MS fragmentation patterns. This method allows an organic analyte to be identified (with reasonable certainty) as an alkane, a ketone, an aldehyde, etc., and may also determine its molecular weight. The method usually does not, however, allow the unambiguous identification of structural isomers, and this ambiguity increases with analyte molecular weight. Many analytes can be tentatively identified with reasonable confidence without having to inject standards of each into the GC/MS to determine their GC retention times or specific MS patterns.

By the nature of the sampling devices, virtually all organic vapors present in the tank headspace are collected by both TST and SUMMA ${ }^{\mathrm{TM}}$ samples. Analyses of the samples are designed to recover, separate, identify, and quantify the organic vapors in the samples. TSTs are not good for collecting highly volatile compounds (i.e., molecules more volatile than propane), but are quite good for most others. In contrast, the recovery of very low volatility compounds (e.g., molecules with more than about 15 carbon atoms) and some polar compounds with moderate volatility (e.g., butanal) from SUMMA ${ }^{\text {TM }}$ samples has been problematic.

The list of tentatively identified compounds recovered from SUMMA ${ }^{\mathrm{TM}}$ samples, with estimated concentrations, is given in Table 4-6. Compounds are listed in Table 4-6 in the order by which they eluted chromatographically, and only non-zero results are included in the reported averages. Because the list of tentatively identified organic compounds in SUMMA ${ }^{\mathrm{TM}}$ samples is rather long and difficult to analyze, the list has been sorted alphanumerically by compound name in Table 4-7, and also in order of decreasing . estimated concentrations in Table 4-8. Numbers in the first columns of Tables 4-7 and 4-8 (Cmpd \#) identify the location of the compounds in Table 4-6. Estimated concentrations are in $\mathrm{mg} / \mathrm{m}^{3}$, based on dry air at $0^{\circ} \mathrm{C}$ and 1.01 bar.

The list of tentatively identified compounds detected in TST samples, and their estimated concentrations, are given in Table 4-9. Compounds are listed in Table 4-9 according to the order by which they eluted chromatographically. The averages reported by ORNL in Table 4-9 are all 3-sample averages, and if an analyte was not detected in a sample, its concentration in that sample was considered to be zero for averaging purposes. Because the list of tentatively identified organic compounds in TST samples is rather long and difficult to analyse, the list has been sorted alphanumerically by compound name in Tables 4-10, and also in order of decreasing estimated concentrations in Table 4-11. Numbers in the first columns of Tables 4-10 and 4-11 (Cmpd \#) identify the location of the compounds in Table 4-9. Estimated concentrations are in $\mathrm{mg} / \mathrm{m}^{3}$, based on $\mathrm{dry}$ air at $0^{\circ} \mathrm{C}$ and 1.01 bar.

The ORNL and PNL methods used to tentatively identify and estimate concentrations are described by Jęnkins et al. (1995a) and Klinger et al. (1995a), respectively, and should be reviewed before this data is used for decision making. Concentrations given in Tables 4-6 through 4-11 should be considered rough estimates. Results in Tables 4-6 through 4-11 are presented in terms of observed chromatographic peaks, and are not adjusted for the occurrence of split peaks (e.g., Cmpd \# 123 and 124 in Table 4-9) or the assignment of the same identity to different peaks (e.g., Cmpd \# 105 and 113 in Table 4-9). In these instances, the estimated concentration of a compound appearing in more than 1 peak is simply the sum of the individual peak estimates. 
WHC-SD-WM-ER-459 Rev.1

\subsection{Total Nonmethane Organic Carbon}

OGIST measured the TNMOC concentration in 3 SUMMATM canister samples using the EPA TO-12 method (Rasmussen 1994a). The sample mean was [313 mg/m $\mathrm{m}^{3}$, with a standard deviation of about [5 $\left.\mathrm{mg} / \mathrm{m}^{3}\right]$. Though data on other tanks is limited, this value is much higher than typical for the waste tanks sampled to date.

A comparable analysis of 1 TST sample by gas chromatography with flame ionization detection indicated the organic vapor concentration to be $296 \mathrm{mg} / \mathrm{m}^{3}$ (Jenkins et al. 1995a). This is in excellent agreement with the EPA TO-12 result. EPA TO-12 method TNMOC measurements of other waste tanks have ranged from as high as $\left[5,000 \mathrm{mg} / \mathrm{m}^{3}\right]$ in tank C-103 (Rasmussen and Einfeld 1994), to as low as $\left[0.18 \mathrm{mg} / \mathrm{m}^{3}\right]$ in tank C-111 (Rasmussen 1994C), while the TNMOC concentration of clean ambient air ranges from about 0.03 to $0.1 \mathrm{mg} / \mathrm{m}^{3}$.

\subsection{Discussion of Organic Analytes}

It is useful to consider the organic vapors in the waste tanks in terms of their sources. Some organic compounds, particularly semivolatile compounds, were constituents of the waste sent to the tank farms, and are present in the tank headspaces because they are still evaporating from the wastes. Other organic compounds present in the tanks have been produced via chemical and radiolytic reactions of the original organic wastes. The most abundant of these degradation products in tank headspaces are volatile, and most contain functional groups.

Tank C-102 is known to have contained bulk quantities of a semivolatile organic liquid (Carothers 1988), and its presence is still evident in auger samples (Campbell et al. 1995). The high vapor concentrations of the semivolatile normal paraffinic hydrocarbons (NPHs), are understandable given their presence in the waste. In fact, the NPH vapor concentrations are perhaps lower than would be expected if tank $\mathrm{C}-103$ were ventilated (as intended) via the cascade line to tank C-102. For example, ORNL measured the ndodecane and n-tridecane vapor concentrations to be about 40 and 52 ppmv, respectively, in tank C-103, and only about 0.91 and 0.81 ppmv, respectively, in tank C-102.

The organic vapor distributions in tanks C-102 and C-103 are graphically illustrated in Figures 4-1 and 4-2. A total ion chromatogram for a SUMMA ${ }^{\mathrm{TM}}$ sample from tank $\mathrm{C}-102$ is displayed in the upper half of both figures (the same chromatogram appears in both figures). In the lower halves of the figures, a similar total ion chromatogram for a SUMMA ${ }^{\text {TM }}$ sample from tank $\mathrm{C}-103$ is displayed. In Figure 4-1, the ordinate scale of the tank C-103 (lower) chromatogram has been adjusted to reveal detail comparable to that given in the tank C-102 (upper) chromatogram. Note, however, that in Figure 4-1 the tallest peaks of the tank C-103 (lower) chromatogram (i.e., at 44 and 48 minutes) are off-scale, and are truncated. In Figure 4-2, the . ordinate scale of the tank C-103 (lower) chromatogram has been adjusted so that these tallest peaks are not off-scale.

In Figures 4-1 and 4-2, the abscissa of the chromatograms is elution time, and the ordinate is instrumental response. The mixture of organic compounds in each sample has been separated chromatographically so that, inasmuch as the separation is complete, individual analytes elute at different times and appear as individual peaks. Each peak height is roughly proportional to the concentration of the associated analyte present in the sample. Rough comparisons of the concentrations of compounds in tanks C-102 and C103 can be made by considering that the propanone peak, appearing as a relatively tall peak at about 9 min in both chromatograms of Figure 4-1, is about 3.8 ppmv in the tank C-102 sample, and about 19.3 ppmv in the tank C-103 sample (Huckaby and Story 1994). 
The tallest peak in the tank C-102 (upper) chromatogram of Figure 4-1, at about $18 \mathrm{~min}$, is due to 1 butanol. The 5 next tallest peaks in the tank $\mathrm{C}-102$ chromatogram are $n$-decane (at $36 \mathrm{~min}$ ), n-undecane (at $40 \mathrm{~min}$ ), n-dodecane (at $44 \mathrm{~min}$ ), n-tridecane (at $48 \mathrm{~min}$ ), and n-tetradecane (at $52 \mathrm{~min}$ ). These are the semivolatile NPHs. Generally, the more volatile a compound is, the faster it elutes through the $\mathrm{GC}_{\text {, }}$ so the volatile compounds are to the left in the chromatograms, and the semivolatile compounds are to the right.

Examination of Figures 4-1 and 4-2 indicates many similarities between the organic vapor distributions of tanks $\mathrm{C}-102$ and $\mathrm{C}-103$. Of particular interest are the peaks scattered amongst the NPH peaks between about 40 and $52 \mathrm{~min}$ in both chromatograms in Figure 4-2. These peaks are from semivolatile organic compounds, and are thought to be impurities of the NPH PUREX process diluent. The locations and relative heights of these peaks in the 2 chromatograms are so similar that either the semivolatile paraffinic liquids in tanks C-102 and C-103 came from the same batch of PUREX process diluent, and/or these headspace constituents are being transported via the cascade line from tank $\mathrm{C}-103$ to tank $\mathrm{C}-102$. Waste transfer history does suggest that the organic liquid currently present in tank C-103 may have come from tank C-102 (Carothers 1988).

The relationship between the organic vapors in tanks C-102 and C-101 has been examined by Huckaby and Bratzel (1995). A visual comparison of the organic vapor distributions in tanks C-102 and C-101 is provided in Figure 4-3 (Klinger et al. 1995a, Lucke et al. 1995b). The ordinate scales in these 2 chromatograms are different, as are the amounts of sample analyzed, but the peak height-to: concentration relationships are similar. Specifically, the tallest peak in the tank C-101 (lower) chromatogram, at about $44 \mathrm{~min}$, has an estimated concentration of $15.2 \mathrm{mg} / \mathrm{m}^{3}$, while the corresponding peak in the tank $\mathrm{C}$-102 (upper) chromatogram (also at about $44 \mathrm{~min}$ ), has an estimated concentration of $13.5 \mathrm{mg} / \mathrm{m}^{3}$.

Comparison of the chromatograms in Figure 4-3 suggests that tank C-101 has its own supply of semivolatile organic waste, and that the cascade line between them does not allow significant transfer of semivolatile organic vapors from tank C-101 to tank C-102. Specifically, the non-NPH semivolatile paraffinic compounds present in tank C-102 are at relatively low concentrations and appear wellseparated in the tank C-102 (upper) chromatogram in Figure 4-3. By contrast, the concentrations of compounds eluting between n-undecane (at $40 \mathrm{~min}$ ) and n-tetradecane (at $52 \mathrm{~min}$ ) in the tank $\mathrm{C}$-101 chromatogram are so much higher that they are no longer separated by the GC. The major analytes in this region were tentatively identified as branched alkanes, cyclic alkanes, and alkenes (Huckaby and Bratzel 1995). Careful examination of the locations and relative heights of these non-NPH compound peaks suggests that there are strong similarities between the organic wastes, and that tank C-101 may have stored the same organic liquid waste as tanks C-102 and C-103.

TST sample chromatograms from tanks $\mathrm{C}-101, \mathrm{C}-102$, and $\mathrm{C}-103$ are similar in character to the SUMMA ${ }^{\text {TM }}$ sample chromatograms (Jenkins et al. 1995c, 1995a, 1994). Like the chromatograms shown in Figures 4-1 and 4-3, the TST chromatograms indicate that tank C-101 has a much higher concentration of non-NPH semivolatile organic vapors than does tank C-102.

Given the apparent semivolatile organic waste similarities, it is not clear whether tank C-103 was breathing, as intended, via the cascade line with tank C-102 when their headspaces were sampled. Likewise, the data does not clearly indicate whether or not tank C-101 is breathing via its cascade line with tank C-102. However, the data do indicate that the cascade lines between tanks C-102 and C-103, and between tanks C-102 and C-101 do not transport significant amounts of the semivolatile organic vapors.

The volatile constituents identified in the SUMMA ${ }^{\mathrm{TM}}$ and TST samples from tank C-102 are generally thought to be chemical and radiolytic reaction products of the semivolatile organic compounds. 


\section{WHC-SD-WM-ER-459 Rev.1}

Supporting this is the fact that several compounds of each homologous series are commoniy found in this as well as other waste tanks. Specifically, the following homologous series of straight-chain compounds were identified in tank C-102 samples:

- 2-ketones, from propanone through 2-nonanone;

- aldehydes, including ethanal, from butanal through octanal;

- nitriles, from ethanenitrile through octanenitrile;

- alkanes, including methane, from propane through n-nonane; and

- 1-alkenes, from propene through 1-octene.

Similarities between the volatile organic compounds in tanks C-101, C-102, and C-103 are evident in Figures 4-1 and 4-3. Many peaks are common to the chromatograms of all 3 tanks, and many have similar relative peak heights. However, transport of these vapors from either tanks $\mathrm{C}-101$ or $\mathrm{C}-103$ would not completely account for the volatile compounds in tank $\mathrm{C}-102$. The concentration of 1 -butanol, for example, is much more prominent amongst the volatile constituents in tank C-102 than it is in either tanks $\mathrm{C}-101$ or $\mathrm{C}-103$. Furthermore, because the volatile organic vapors are thought to be produced by the degradation 'of the semivolatile organics (which appear to be very similar in tanks C-102 and C-103), the types and relative concentrations of volatile organic compounds in these tanks would be expected to be very similar, even if the cascade lines between them allowed no transport of vapors. 


\subsection{SUMMARY}

The tank C-102 headspace was sampled in September 1994 for gases and vapors to address flammability and industrial hygiene concerns. Collection and analysis of samples has been reported. It was determined that no headspace constituents exceeded the flammability notification limits, but ammonia, measured to be $189 \mathrm{ppmv}$, exceeded the industrial hygiene notification limit specified in the current Vapor Sampling and Analysis Plan (Homi 1995). 


\section{THIS PAGI INTENIIONAUTY}

IFIT BLANK 
WHC-SD-WM-ER-459 Rev.1

\subsection{REFERENCES}

29 CFR 1910.120, 1993, "Hazardous Waste Operations and Emergency Response", Code of Federal Regulations.

Anderson, J. D., 1990, A History of the 200 Area Tank Farms, WHC-MR-0132, Westinghouse Hanford Company, Richland, Washington.

Burnum, S. T., 1995, Qualification of Reported WHC Vapor Program Data, (letter 95-CHD-065 to president, Westinghouse Hanford Company, August 18); Department of Energy, Richiand Operations Office, Richland, Washington.

Campbell, J. A., R. M. Bean, K. L. Wahl, G. M. Wong, K. E. Bell, K. B. Wehner, A. D. Rice, R. J. Ray, D. B. Bechtold, B. R. Wels, R. W. Schroeder, J. W. Ball, B. D. Valenzuela, J. M. Frye, S. L. Fitzgerald, P. P. Bachelor, B. Griffin, R. K. Fuller, A. B. Benally, and S. M. Parong, 1995, Analysis of Samples from Hanford Waste Tanks 241-C-102, 241-BY-108, and 241-C-103, PNL-10531, UC-601, Pacific Northwest Laboratory, Richland, Washington.

Carothers, K. G., 1988, Tank 103-C Transaction History - Post January 1976, (internal memorandum 13331-88-600 to D. A. Dodd, G. L. Dunford, G. N. Hanson, A. W. Lilly, and R. E. Van der Cook, September 22), Westinghouse Hanford Company, Richiand, Washington.

Cashdollar, K. L., M. Hertzberg, I. A. Zlochower, C. E. Lucci, G. M. Green, and R. A. Thomas, 1992, Laboratory Flammability Studies of Mixtures of Hydrogen, Nitrous Oxide, and Air, WHC-SD-WMES-219 Rev. 0, Westinghouse Hanford Company, Richland, Washington.

Conrad, R. B., 1994, Engineering Evaluation of Alternatives for Treatment of Tank 241-C-103 Vapor Space, WHC-SD-WM-ES-281, Rev. 0, Westinghouse Hanford Company, Richland, Washington.

Dougherty, L. F., 1995, Single Shell Tank Interim Operational Safety Requirements, WHC-SD-WM-OSR005 Rev. 0, Westinghouse Hanford Company, Richland, Washington.

EPA 1988, Compendium of Methods for the Determination of Toxic Organic Compounds in Ambient Air, PB90-127374, U.S. Environmental Protection Agency, Washington, D.C.

EPA 1992, Test Methods for Evaluating Solid Waste, SW-846 Rev. 1, U.S. Environmental Protection Agency, Washington, D.C.

Hendrickson, R. W., 1995, Tank Vapor Characterization Oak Ridge National Laboratories Quality Assurance Assessment, TWRSQA-95-0012, Westinghouse Hanford Company, Richland, Washington.

Homi, C. S., 1995, Vapor Sampling and Analysis Plan, WHC-SD-WM-TP-335 Rev. 0G, Westinghouse Hanford Company, Richland, Washington.

Huckaby, J. L., 1994, Tank 241-C-103 Headspace Flammability, WHC-EP-0734 Rev. 1, Westinghouse Hanford Company, Richland, Washington. 


\section{WHC-SD-WM-ER-459 ReV.1}

Huckaby, J. L., H. Babad, and D. R. Bratzel, 1995, Headspace Gas and Vapor Characterization Summary for the 43 Vapor Program Suspect Tanks, WHC-SD-WM-ER-514 Rev. 0, Westinghouse Hanford Company, Richland, Washington.

Huckaby, J. L., and Bratzel, 1995a, Tank 241-C-101 Headspace Gas and Vapor Characterization Results for Samples Collected in September 1994, WHC-SD-WM-ER-458 Rev. 1, Westinghouse Hanford Company, Richland, Washington.

Huckaby, J. L., and M. S. Story, 1994, Vapor Characterization of Tank 241-C-103, WHC-EP-0780 Rev. 0, Westinghouse Hanford Company, Richland, Washington.

Jenkins, R. A., 1995a, Untitled, (Letter 090195A to D. Bratzel, September 1), Oak Ridge National Laboratory, Oak Ridge, Tennessee.

Jenkins, R. A., 1995b, Untitled, (Letter 091495A to D. Bratzel, September 14), Oak Ridge National Laboratory, Oak Ridge, Tennessee

Jenkins, R. A, A. B. Dindal, C. E. Higgins, C. Y. Ma, M. A. Palausky, J. T. Skeen, and C. K. Bayne, 1995a, Analysis of Tank 241-C-102 Headspace Components, ORNL-CASD-FR-241C102.95, Rev. 1, Oak Ridge National Laboratory, Oak Ridge, Tennessee.

Jenkins, R. A. A. B. Dindal, C. Y. Ma, M. A. Palausky, J. T. Skeen, and C. K. Bayne, 1995b, Analysis of Tank 241-TY-104 Headspace Components, ORNL-CASD-FR-241TY104.95 Rev. 1, Oak Ridge National Laboratory, Oak Ridge, Tennessee

Jenkins, R. A, A. B. Dindal, C. E. Higgins, C. Y. Ma, M. A. Palausky, and J. T. Skeen, 1995c, Analysis of Tank 241-C-101 Headspace Components, ORNL-CASD-FR-241C101.95 Rev. 1, Oak Ridge National Laboratory, Oak Ridge, Tennessee.

Jenkins, R. A, A. B. Dindal, C. E. Higgins, C. Y. Ma, J. T. Skeen, and R. R. Smith, 1994, Analysis of Tank 241-C-103 Headspace Components from Sampling Job 7B, Oak Ridge National Laboratory, Oak Ridge, Tennessee.

Keller, K. K., 1994, Quality Assurance Project Plan for Tank Vapor Characterization, WHC-SD-WMQAPP-013 Rev. 2, Westinghouse Hanford Company, Richland, Washington.

Klinger, G. S., T. W. Clauss, M. W. Ligotke, K. H. Pool, R. B. Lucke, B. D. MoVeety, K. B. Olsen, O. P. Bredt, J. S. Fruchter, and S. C. Goheen, 1995a, Vapor Space Characterization of Waste Tank 241-C-102: Results from Samples Collected on 8/23/94, PNL-10646 UC-606, Pacific Northwest Laboratory, Richland, Washington.

Klinger, G. S., T. W. Clauss, M. W. Ligotke, K. H. Pool, R. B. Lucke, B. D. McVeety, O. P. Bredt, J. S. Young, M. McCulloch, J. S. Fruchter, and S. C. Goheen, 1995b, Vapor Space Characterization of Waste Tank 241-TX-105: Results from Samples Collected Through the Vapor Sampling System on 12/20/94, PNL-10594 UC-606, Pacitic Northwest Laboratory, Richland, Washington.

Ligotke, M. W. 1995, PNL Vapor Prloject Analytical Holding Times, (Letter to.D. R. Bratzel, September 23), Pacific Northwest Laboratory, Richland, Washington. 
Lucke, R. B., M. W. Ligotke, K. H. Pool, T. W. Clauss, A. K. Sharma, B. D. McVeety, M. McCulloch, J. S. Fruchter, and S. C. Goheen, 1995a, Vapor Space Characterization of Waste Tank 241-C-108: Results from Samples Collected Through the Vapor Sampling System on 8/5/94, PNL-10351 UC606, Pacific Northwest Laboratory, Richland, Washington.

Lucke, R. B., T. W. Clauss, M. W. Ligotke, K. H. Pool, B. D. McVeety, J. S. Young, M. McCulloch, J. S. Fruchter, and S. C. Goheen, 1995b, Vapor Space Characterization of Waste Tank 241-C-101: Results from Samples Collected Through the Vapor Sampling System on 9/1/94, PNL-10491 UC606 , Pacific Northwest Laboratory, Richland, Washington.

Mahium, D. D., J. Y. Young, and R. E. Weller, 1994, Toxicologic Evaluation of Analytes from Tank 231-C103, PNL-10189, Pacific Northwest Laboratory, Richland, Washington.

McVeety, B. D., T. W. Clauss, M. W. Ligotke, K. H. Pool, R. B. Lucke, G. S. Klinger, J. S. Young, M. McCulloch, J. S. Fruchter, and S. C. Goheen, 1995, Vapor Space Characterization of Waste Tank 241-BY-108: Results from Samples Collected on 10/27/94, PNL-10495 UC-606, Pacific Northwest Laboratory, Richland, Washington.

Meacham, J. E., H. Babad, R. J. Cash, G. T. Dukelow, S. J. Eberlein, D. W. Hamilton, G. D. Johnson, J. W. Osborne, M. A. Payne, D. J. Sherwood, D. A. Turner, and J. L. Huckaby, 1995, Approach for Tank Safety Characterization of Hanford Site Waste, WHC-EP-0843 Rev. 0, UC-2070, Westinghouse Hanford Company, Richland, Washington.

NFPA 1992, Standard on Explosion Prevention Systems, NFPA 69, National Fire Protection Association, Quincy, Massachusetts

Osborne, J. W., and J. L. Huckaby, 1994, Program Plan for the Resolution of Tank Vapor Issues, WHCEP-0562 Rev. 1, Westinghouse Hanford Company, Richland, Washington.

Osborne, J. W., J. L. Huckaby, T. P. Rudoiph, E. R. Hewitt, D. D. Mahlum, J. Y. Young, and C. M. Anderson, 1994, Data Quality Objectives for Generic In-Tank Health and Safety Issue Resolution, WHC-SD-WM-DQO-002, Westinghouse Hanford Company, Richland, Washington.

Pool, K. H, and R. M. Bean, 1994, Analysis of Liquid Samples from Hanford Waste Tank 241-C-103, PNL9403 UC-601, Pacific Northwest Laboratory, Richland, Washington.

Rasmussen, R. A., 1994a, Air Samples Collected at Waste Tank 241-C-102 on August 23, 1994 by Westinghouse Hanford in 6-L SS SUMMA@ Canisters, Oregon Graduate institute of Science and Technology, Beaverton, Oregon.

Rasmussen, R. A., 1994b, Air Samples Collected at Waste Tank 241-C-101 on September 1, 1994 by Westinghouse Hanford in 6-L SS SUMMA® Canisters, Oregon Graduate Institute of Science and Technology, Beaverton, Oregon.

Rasmussen, R. A., 1994c, Air Samples Collected at Waste Tank 241-C-111 on September 13, 1994 by Westinghouse Hanford in 6-L SS SUMMA@ Canisters, Oregon Graduate Institute of Science and Technology, Beaverton, Oregon.

Rasmussen, R. A., and W. Einfeld, 1994, Hanford Tank 103-C Analyses and Method Validation Development Phase, SAND94-1807, Sandia National Laboratories, Albuquerque, New Mexico. 


\section{WHC-SD-WM-ER-459 Rev.1}

WHC 1995a, Operating Specifications for Watchlist Tanks, OSD-T-151-00030, Rev. B-9, Westinghouse Hanford Company, Richland, Washington.

WHC 1995b, Vapor and Gas Sampling of Single-Shell Tank 241-C-102 Using the Vapor Sampling System, WHC-SD-WM-RPT-127, Westinghouse Hanford Company, Richland, Washington. 


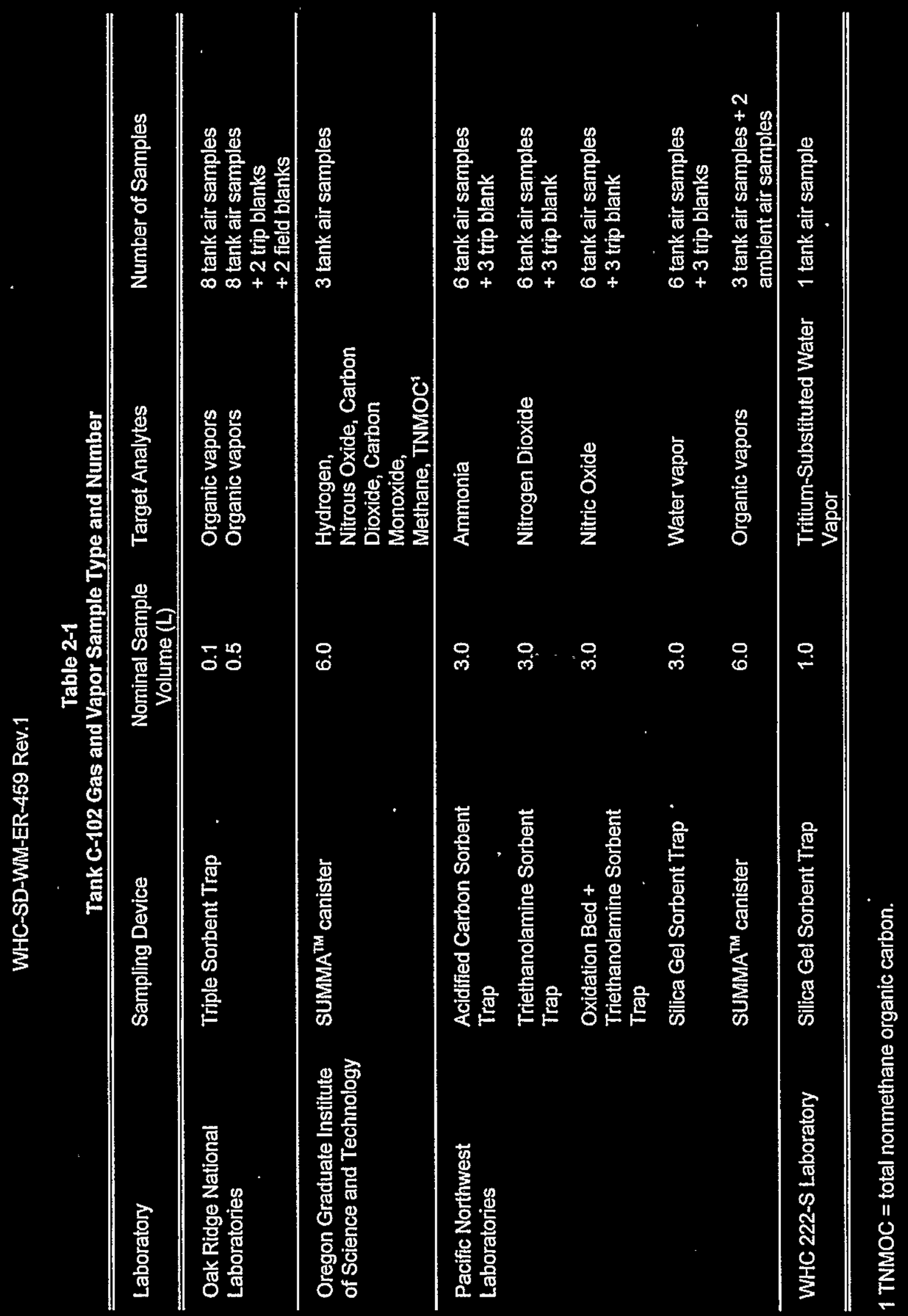


WHC-SD-WM-ER-459 Rev.1

Table 3-1

Tank C-102 Inorganic Gas and Vapor Concentrations

Analyses by Oregon Graduate Institute of Science and Technology and Pacific Northwest Laboratory

\begin{tabular}{|c|c|c|c|c|c|c|}
\hline Compound & $\begin{array}{c}\mathrm{CAS}^{1} \\
\text { number }\end{array}$ & $\begin{array}{l}\text { Sample } \\
\text { Type }\end{array}$ & $\begin{array}{c}\text { Number } \\
\text { of } \\
\text { samples }\end{array}$ & $\begin{array}{c}\text { Average }^{2} \\
\text { (ppmv) }\end{array}$ & $\begin{array}{c}\text { Standard } \\
\text { Deviation }{ }^{2} \\
\text { (ppmv) }\end{array}$ & $\begin{array}{c}\mathrm{RSD}^{2,3} \\
(\%)\end{array}$ \\
\hline Ammonia, $\mathrm{NH}_{3}$ & $7664-41-7$ & Sorbent Trap & 6 & 189 & 3 & 1.6 \\
\hline Carbon Dioxide, $\mathrm{CO}_{2}$ & $124-38-9$ & SUMMA $^{\mathrm{M}}$ & 3 & [8.2] & {$[0.36]$} & [4] \\
\hline Carbon Monoxide, Co & $630-08-0$ & SUMMA ${ }^{\text {TM }}$ & 3 & {$[4.0]$} & {$[0.64]$} & [16] \\
\hline Hydrogen, $\mathrm{H}_{2}$ & $1333-74-0$ & SUMMA ${ }^{\text {TM }}$ & 3 & [133] & [2.64] & [2] \\
\hline Nitric Oxide, NO & $10102-43-9$ & Sorbent Trap & 6 & 0.24 & 0.04 & 17 \\
\hline Nitrogen Dioxide, $\mathrm{NO}_{2}$ & $10102-44-0$ & Sorbent Trap & 6 & $\leq 0.05$ & - & - \\
\hline Nitrous Oxide, $\mathrm{N}_{2} \mathrm{O}$ & $10024-97-2$ & SUMMA ${ }^{T M}$ & 3 & [154] & [1.53] & [1] \\
\hline Water Vapor, $\mathrm{H}_{2} \mathrm{O}$ & $7732-18-5$ & Sorbent Trap & 6 & $\begin{array}{l}28,400 \\
\quad(20.4 \mathrm{mg} / \mathrm{L})\end{array}$ & $\begin{array}{l}1,500 \\
(1.1 \mathrm{mg} / \mathrm{L})\end{array}$ & 5 \\
\hline
\end{tabular}

$1 \mathrm{CAS}=$ Chemical Abstracts Service.

2 Bracketed values are from OGIST and should be considered secondary results, non-bracketed values are from PNL and should be considered primary results.

3 RSD = relative standard deviation. Burnum (1995) specifies the RSD should be less than $25 \%$. 
Table 3-2

Comparison of Tank C-101, C-102, and C-103 Headspace Constituents -Inorganic Analyses by Oregon Graduate Institute of Science and Technology and Organic Analyses by Oak Ridge National Laboratory"

\begin{tabular}{|c|c|c|c|}
\hline Tank: & $\mathrm{C}-101^{2}$ & C-102 & $\mathrm{C}-103^{3}$ \\
\hline Date sampled, (mo/day/yr) & $9 / 1 / 94$ & $8 / 23 / 94$ & $\begin{array}{l}4 / 7 / 94- \\
5 / 25 / 94\end{array}$ \\
\hline Headspace temperature, $\left({ }^{\circ} \mathrm{C}\right)$ & 34 & 25.8 & 38 \\
\hline Ammonia, (ppmv) & 98 & 189 & 304 \\
\hline Hydrogen, (ppmv) & [436] & [133] & [782] \\
\hline Carbon dioxide, (ppmv) & [1426] & [8.2] & - \\
\hline Carbon monoxide, (ppmv) & [15.5] & {$[4.0]$} & [26.7] \\
\hline Nitric oxide, (ppmv) & 1.5 & 0.24 & 1.5 \\
\hline Nitrogen dioxide, (ppmv) & $\leq 0.04$ & $\leq 0.05$ & $\leq 0.04$ \\
\hline Nitrous oxide, (ppmv) & [642] & [154] & [763] \\
\hline Water vapor, $\left(\mathrm{mg} / \mathrm{m}^{3}\right)$ & 30.1 & 20.4 & 42.2 \\
\hline Water vapor, (\% relative humidity) & 80 & 85 & 91 \\
\hline Ethanenitrile (acetonitrile), (ppmv) & 0.69 & 0.34 & $(9.1)$ \\
\hline Propanone (acetone), (ppmv) & $(1.0)$ & $(2.2)$ & $(8.8)$ \\
\hline 1-Butanol, (ppmv) & 0.46 & (7.6) & $(28.4)$ \\
\hline n-Dodecane, (ppmv) & $(0.94)$ & $(0.91)$ & $(40.3)$ \\
\hline n-Tridecane, (ppmv) & $(0.61)$ & $(0.81)$ & $(52.0)$ \\
\hline Total nonmethane organic compounds, $\left(\mathrm{mg} / \mathrm{m}^{3}\right)$ & [256] & [313] & $\begin{array}{r}{[3,000-} \\
5,000]^{4} \\
\end{array}$ \\
\hline
\end{tabular}

1 Where PNL inorganic gas or vapor data was unavailable, OGIST results are listed. OGIST data is given in brackets to indicate the data should be considered secondary results. Organic vapor results are from ORNL, with non-quantitative values in parentheses and quantitative values not in parentheses.

2 Data are from Huckaby and Bratzel 1995.

3 Tank C-103 was sampled on various dates; data are from Huckaby and Story 1994.

4 TNMOC concentrations were too high for precise measurement; this range is from Rasmussen and Einfeld 1994. 
WHC-SD-WM-ER-459 Rev.1

Table 4-1

Tank C-102 Quantitatively Measured Compounds in SUMMA ${ }^{\text {TW }}$ Samples -Analyses by Pacific Northwest Laboratory

\begin{tabular}{clcccc}
\hline $\begin{array}{c}\text { Cmpd } \\
\#\end{array}$ & Compound & $\begin{array}{c}\text { CAS }^{1} \\
\text { Number }\end{array}$ & $\begin{array}{c}\text { Average } \\
\text { (ppmv) }\end{array}$ & $\begin{array}{c}\text { Standard } \\
\text { Deviation } \\
\text { (ppmv) }\end{array}$ & $\begin{array}{c}\text { RSD }^{3} \\
(\%)\end{array}$ \\
\hline \hline 1 & Methane $^{4}$ & $74-82-8$ & {$[4.9]$} & {$[0.06]$} & {$[1.2]$} \\
2 & Ethanenitrile (acetonitrile) & $75-05-8$ & 0.33 & 0.04 & 12 \\
3 & Propanone (acetone) & $67-64-1$ & 3.18 & 0.54 & 17 \\
4 & Trichlorofluoromethane & $75-69-4$ & 0.051 & 0.008 & 16 \\
5 & Propanenitrile & $107-12-0$ & 0.058 & 0.0004 & 0.7 \\
6 & Propanol & $71-23-8$ & 0.21 & 0.003 & 1.2 \\
7 & 2-Butanone & $78-93-3$ & 0.72 & 0.013 & 1.8 \\
8 & n-Hexane & $110-54-3$ & 1.62 & 0.029 & 1.8 \\
9 & Tetrahydrofuran & $109-99-9$ & 0.28 & 0.005 & 1.7 \\
10 & n-Butanenitrile & $109-74-0$ & 0.083 & 0.002 & 2.5 \\
11 & Cyclohexane & $110-82-7$ & 0.031 & 0.002 & 6 \\
12 & n-Heptane & $142-82-5$ & 0.20 & 0.005 & 2.4 \\
13 & 4-Methyl-2-Pentanone & $108-10-1$ & 0.046 & 0.003 & 6 \\
14 & Pyridine & $110-86-1$ & 0.019 & 0.001 & 5 \\
15 & Toluene & $108-88-3$ & 0.006 & 0.0004 & 7 \\
16 & Cyclohexanone & $108-94-1$ & 0.015 & 0.0008 & 5 \\
17 & n-Decane & $124-18-5$ & 0.64 & 0.042 & 6 \\
\hline \hline
\end{tabular}

$1 \mathrm{CAS}=$ Chemical Abstract Service.

2 Average of 3 samples.

3 RSD = relative standard deviation. Burnum (1995) specifies the RSD should be less than $25 \%$.

4 Methane results were performed by OGIST and should be considered a secondary result (Rasmussen 1994a). All others are from Klinger et al. (1995a). 


\section{WHC-SD-WM-ER-459 Rev.1}

Table 4-2

Tank C-102 Quantitatively Measured Organic Compounds in TST Samples -Analyses by Oak Ridge National Laboratory ${ }^{1}$

\begin{tabular}{clcccc}
\hline \hline $\begin{array}{c}\text { Cmpd } \\
\#\end{array}$ & Compound & $\begin{array}{c}\text { CAS }^{2} \\
\text { Number }\end{array}$ & $\begin{array}{c}\text { Average }^{3} \\
\text { (ppmv) }\end{array}$ & $\begin{array}{c}\text { Standard } \\
\text { Deviation } \\
\text { (ppmv) }\end{array}$ & $\begin{array}{c}\text { RSD }^{4} \\
(\%)\end{array}$ \\
\hline 1 & Ethanenitrile (acetonitrile) & $75-05-8$ & 0.34 & 0.04 & 11 \\
2 & n-Hexane & $110-54-3$ & 0.097 & 0.008 & 8 \\
3 & n-Butanenitrile & $109-74-0$ & 0.061 & 0.005 & 9 \\
4 & n-Heptane & $142-82-5$ & 0.085 & 0.012 & 15 \\
5 & 2-Hexanone & $591-78-6$ & 0.072 & 0.009 & 12 \\
6 & n-Octane & $111-65-9$ & 0.071 & 0.008 & 11 \\
7 & n-Hexanenitrile & $628-73-9$ & 0.030 & 0.001 & 4 \\
8 & 2-Heptanone & $110-43-0$ & 0.079 & 0.024 & 31 \\
9 & n-Nonane & $111-84-2$ & 0.069 & 0.005 & 8 \\
10 & n-Heptanenitrile & $629-08-3$ & 0.032 & 0.005 & 15 \\
11 & 2-Octanone & $111-13-7$ & 0.043 & 0.019 & 44 \\
12 & n-Decane & $124-18-5$ & 0.27 & 0.05 & 18 \\
\hline \hline
\end{tabular}

1 Results in this table are quantitative (as defined in Section 4.1).

$2 \mathrm{CAS}=$ Chemical Abstract Service.

3 Average of $3,200 \mathrm{ml}$ TST samples.

4 RSD = relative standard deviation. Burnum (1995) specifies the RSD should be less than $25 \%$. 
WHC-SD-WM-ER-459 Rev.1

Table 4-3

Tank C-102 Positively Identified Organic Compounds in TST Samples Analyses by Oak Ridge National Laboratory'

\begin{tabular}{clcccc}
\hline \hline $\begin{array}{c}\text { Cmpd } \\
\#\end{array}$ & Compound & $\begin{array}{c}\text { CAS }^{2} \\
\text { Number }\end{array}$ & $\begin{array}{c}\text { Average } \\
\text { (ppmv) }\end{array}$ & $\begin{array}{c}\text { Standard } \\
\text { Deviation } \\
\text { (ppmv) }\end{array}$ & $\begin{array}{c}\mathrm{RSD}^{4} \\
(\%)\end{array}$ \\
\hline \hline 1 & $\begin{array}{l}\text { Dichloromethane (methylene } \\
\text { chloride) }\end{array}$ & $75-09-2$ & 0.043 & 0.045 & 104 \\
2 & Propanenitrile & $107-12-0$ & .0 .043 & 0.001 & 3 \\
3 & Benzene & $71-43-2$ & 0.32 & 0.31 & 98 \\
4 & Toluene & $108-88-3$ & 0.082 & 0.072 & 88 \\
5 & n-Undecane & $1120-21-4$ & 0.70 & 0.13 & 19 \\
6 & n-Dodecane & $112-40-3$ & 0.91 & 0.10 & 11 \\
7 & n-Tridecane & $629-50-5$ & 0.81 & 0.15 & 19 \\
8 & Dibutyl butylphosphonate & $78-46-6$ & 0.0050 & 0.0012 & 24 \\
9 & Tributyl phosphate & $126-73-8$ & 0.075 & 0.007 & 10 \\
\hline \hline
\end{tabular}

1 Results in this table are not quantitative (as defined in Section 4.1 ) because measured values in at least 1 of the samples are outside instrument calibration limits.

2 CAS = Chemical Abstract Service.

3 Average of $3,200 \mathrm{ml}$ TST samples.

4 RSD = relative standard deviation. Burnum (1995) specifies the RSD should be less than $25 \%$. 
WHC-SD-WM-ER-459 Rev.1

Table 4-4

Tank C-102 Positively Identified Organic Compounds in TST Samples for which Practical Holding Times were Exceeded Analyses by Oak Ridge National Laboratory ${ }^{1}$

\begin{tabular}{clcccc}
\hline $\begin{array}{c}\text { Cmpd } \\
\#\end{array}$ & Compound & $\begin{array}{c}\text { CAS }^{2} \\
\text { Number }\end{array}$ & $\begin{array}{c}\text { Average }^{3} \\
\text { (ppmv) }\end{array}$ & $\begin{array}{c}\text { Standard } \\
\text { Deviation } \\
\text { (ppmv) }\end{array}$ & $\begin{array}{c}\text { RSD }^{4} \\
(\%)\end{array}$ \\
\hline \hline 1 & Propanone $^{5}$ (acetone) & $67-64-1$ & 2.2 & 0.5 & 22 \\
2 & Butanal $^{5}$ & $123-72-8$ & 2.6 & 1.7 & 64 \\
3 & 1-Butanol & $71-36-3$ & 7.6 & 1.7 & 22 \\
4 & 2-Pentanone & $107-87-9$ & 0.15 & 0.02 & 16 \\
5 & n-Pentanenitrile & $110-59-8$ & 0.030 & 0.001 & 5 \\
\hline \hline
\end{tabular}

1 Practical holding times are defined and discussed in Section 4.1.

$2 \mathrm{CAS}=$ Chemical Abstract Service.

3 Average of 3,200 $\mathrm{ml}$ TST samples.

$4 \mathrm{RSD}=$ relative standard deviation. Burnum (1995) specifies the RSD should be less than $25 \%$.

5 The concentration of this analyte was not quantitatively measured (as defined in Section 4.1 ), because the measured concentration was outside of the instrumental callibration limits.

6 The concentration of this analyte is quantitatively measured (as defined in Section 4.1). 
Table 4-5

Tank C-102 Comparison of Organic Compounds in TST and SUMMA ${ }^{\text {TH }}$ Samples Analyses by Oak Ridge National Laboratory and Pacific Northwest Laboratory

\begin{tabular}{lcccc}
\hline Compound & $\begin{array}{c}\text { CAS }^{1} \\
\text { Number }\end{array}$ & $\begin{array}{c}\text { TST } \\
\text { Average } \\
\text { (ppmv) }\end{array}$ & $\begin{array}{c}\text { SUMMA }^{\text {TM }} \\
\text { Average }^{3} \\
\text { (ppmv) }\end{array}$ & $\begin{array}{c}\text { PRD }^{4} \\
(\%)\end{array}$ \\
\hline 1,1-Dichloroethene (vinylidene chloride) & $75-35-4$ & $<0.00092$ & $<0.005$ & - \\
Dichloromethane (methylene chloride) & $75-09-2$ & 0.043 & $<0.005$ & $>158$ \\
Propanone (acetone) & $67-64-1$ & 2.2 & 3.18 & 36 \\
Ethanenitrile (acetonitrile) & $75-05-8$ & 0.34 & 0.33 & 3 \\
Propanenitrile & $107-12-0$ & 0.043 & 0.058 & 30 \\
n-Butanenitrile & $109-74-0$ & 0.061 & 0.083 & 30 \\
Benzene & $71-43-2$ & 0.32 & $<0.005$ & $>194$ \\
Toluene & $108-88-3$ & 0.082 & 0.006 & 173 \\
n-Hexane & $110-54-3$ & 0.097 & 1.62 & 177 \\
n-Heptane & $142-82-5$ & 0.085 & 0.20 & 81 \\
n-Decane & $124-18-5$ & 0.27 & 0.64 & 81 \\
\hline \hline
\end{tabular}

$1 \mathrm{CAS}=$ Chemical Abstract Service.

2 Average of $3,200 \mathrm{ml}$ TST samples.

3 Average of 3 samples.

$4 \mathrm{PRD}=$ percent relative difference. Keller (1994) requires the PRD to be less than $20 \%$. 
WHC-SD-WM-ER-459 Rev.1

Table 4-6

Tank C-102 Tentatively Identified Compounds in SUMMA ${ }^{\text {TM }}$ Samples in Order of Chromatographic Elution -Analyses by Pacific Northwest Laboratory

\begin{tabular}{|c|c|c|c|c|}
\hline$\underset{\#}{\text { Cmpd }}$ & Compound & $\begin{array}{c}\mathrm{CAS}^{1} \\
\text { Number }\end{array}$ & $\begin{array}{l}\text { Average } \\
\left(\mathrm{mg} / \mathrm{m}^{3}\right)\end{array}$ & $\begin{array}{c}\text { Standard }{ }^{2} \\
\text { Deviation } \\
\left(\mathrm{mg} / \mathrm{m}^{3}\right) \\
\end{array}$ \\
\hline 1 & Propene & $115-07-1$ & 1.36 & 0.05 \\
\hline 2 & Propane & $74-98-6$ & 0.64 & 0.02 \\
\hline 3 & 1-Propyne & $74-99-7$ & 0.60 & 0.02 \\
\hline 4 & Cyclopropane & $75-19-4$ & 0.25 & 0.01 \\
\hline 5 & Ethanal (acetaidehyde) & $75-07-0$ & 0.68 & 0.13 \\
\hline 6 & Methanol (methyl alcohol) & $67-56-1$ & $<0.01$ & - \\
\hline 7 & 1-Butene & $106-98-9$ & 0.61 & 0.09 \\
\hline 8 & n-Butane & $106-97-8$ & 1.09 & 0.37 \\
\hline 9 & 1-Propene, 2-methyl- & $115-11-7$ & 0.12 & 0.02 \\
\hline 10 & Ethanol & $64-17-5$ & 0.16 & 0.02 \\
\hline 11 & 1-Pentene & $108-67-1$ & 0.30 & 0.05 \\
\hline 12 & n-Pentane & $109-66-0$ & 0.62 & 0.10 \\
\hline 13 & 2-Pentanone & $107-87-9$ & $<0.04$ & - \\
\hline 14 & 2-Pentene & $109-68-2$ & $<0.03$ & - \\
\hline 15 & Pentane, 2-methyl- & $107-83-5$ & 0.22 & 0.004 \\
\hline 16 & Butanal & $123-72-8$ & 0.77 & 0.03 \\
\hline 17 & 1-Hexene & $592-41-6$ & 0.35 & 0.01 \\
\hline 18 & Nitric acid, ethyl ester & $625-58-1$ & 0.18 & 0.01 \\
\hline 19 & Nitrous acid, butyl ester ${ }^{3}$ & $544-16-1$ & 0.09 & - \\
\hline 20 & 3-Buten-1-ol & $627-27-0$ & 0.08 & - \\
\hline 21 & Butanal, 3-methyl-3 & $590-86-3$ & 0.08 & - \\
\hline 22 & 2-Butanone, 3-methyl- & $563-80-4$ & 0.13 & 0.003 \\
\hline 23 & 1-Butanol & $71-36-3$ & 27.82 & 3.56 \\
\hline 24 & Nitric acid, 1-methylethyl ester & $1712-64-7$ & 0.15 & 0.01 \\
\hline 25 & 2-Pentanone & $107-87-9$ & 1.61 & 0.03 \\
\hline 26 & Pentanal & $110-62-3$ & 0.90 & 0.01 \\
\hline
\end{tabular}




\begin{tabular}{|c|c|c|c|c|}
\hline Cmpd & Compound & $\begin{array}{c}\text { CAS }^{1} \\
\text { Number }\end{array}$ & $\begin{array}{l}\text { Average } \\
\left(\mathrm{mg} / \mathrm{m}^{3}\right)\end{array}$ & $\begin{array}{c}\text { Standard } 2 \\
\text { Deviation } \\
\left(\mathrm{mg} / \mathrm{m}^{3}\right)\end{array}$ \\
\hline 27 & 1-Heptene & $592-76-7$ & 0.34 & 0.002 \\
\hline 28 & 2-Pentanone, 3-methyl- & $565-61-7$ & 0.083 & 0.002 \\
\hline 29 & Pentanenitrile & $110-59-8$ & 0.16 & 0.001 \\
\hline 30 & 1-Heptanol & $53535-33-4$ & 0.30 & 0.01 \\
\hline 31 & Unknown Alkyl Nitrate & & .0 .083 & 0.004 \\
\hline 32 & Heptane, 2-methyl- & $592-27-8$ & 0.24 & 0.01 \\
\hline 33 & 2-Hexanone & $591-78-6$ & 0.73 & 0.01 \\
\hline 34 & Hexanal & $66-25-1$ & 0.50 & 0.02 \\
\hline 35 & 1-Octene & $111-66-0$ & 0.23 & 0.01 \\
\hline 36 & n-Octane & $111-65-9$ & 1.22 & 0.03 \\
\hline 37 & 2-Hexanone, 5-methyl- & $110-12-3$ & 0.19 & 0.01 \\
\hline 38 & Hexanenitrile & $628-73-9$ & 0.14 & 0.003 \\
\hline 39 & $\begin{array}{l}\text { 2-Furanmethanol, } \\
\text { tetrahydro-4 }\end{array}$ & $97-99-4$ & 0.074 & 0.01 \\
\hline 40 & 2-Heptanone & $110-43-0$ & 0.86 & 0.06 \\
\hline 41 & Heptanal & $111-71-7$ & 0.39 & 0.01 \\
\hline 42 & n-Nonane & $111-84-2$ & 0.87 & 0.02 \\
\hline 43 & Nitric acid, pentyl ester & $1002-16-0$ & 0.16 & 0.01 \\
\hline 44 & 2-Heptanone, 4-methyl- & $6137-06-0$ & 0.082 & 0.002 \\
\hline 45 & 2-Heptanone, 6-methyl- & $928-68-7$ & 1.25 & 0.02 \\
\hline 46 & Cyclohexane, propyl- & $1678-92-8$ & 0.11 & 0.004 \\
\hline 47 & Heptanenitrile & $629-08-3$ & 0.41 & 0.02 \\
\hline 48 & 4-Octanone & $589-63-9$ & 0.11 & 0.004 \\
\hline 49 & Unknown C10 Alkane & & 0.17 & 0.01 \\
\hline 50 & Unknown C10 Alkane & & 0.16 & 0.01 \\
\hline 51 & Unknown Alkane ${ }^{3}$ & & 0.15 & - \\
\hline 52 & 2-Octanone & $111-13-7$ & 0.66 & 0.01 \\
\hline 53 & Cyclohexane, 1,1,2,3-tetramethyl- & $6783-92-2$ & 0.20 & 0.003 \\
\hline 54 & Octanal & $124-13-0$ & 0.25 & 0.03 \\
\hline
\end{tabular}


WHC-SD-WM-ER-459 ReV.1

\begin{tabular}{|c|c|c|c|c|}
\hline $\begin{array}{c}\text { Cmpd } \\
\#\end{array}$ & Compound & $\begin{array}{c}\text { CAS }^{1} \\
\text { Number }\end{array}$ & $\begin{array}{l}\text { Average } \\
\left(\mathrm{mg} / \mathrm{m}^{3}\right)\end{array}$ & $\begin{array}{c}\text { Standard }{ }^{2} \\
\text { Deviation } \\
\left(\mathrm{mg} / \mathrm{m}^{3}\right)\end{array}$ \\
\hline 55 & Unknown C9 Alkene/Cycloalkane & & 0.21 & 0.003 \\
\hline 56 & Unknown C10 Alkene/Cycloalkane ${ }^{4}$ & & 0.10 & 0.01 \\
\hline 57 & Nitric acid, hexyl ester & $20633-11-8$ & 0.079 & 0.002 \\
\hline 58 & Unknown C10 Alkene/Cycloalkane ${ }^{4}$ & & 0.067 & $<0.01$ \\
\hline 59 & Unknown C10 Alkene/Cycloalkane & & 0.074 & 0.007 \\
\hline 60 & Unknown C11 Alkane & & 0.79 & 0.02 \\
\hline 61 & Unknown C11 Alkane & & 0.21 & 0.01 \\
\hline 62 & Unknown C10 Alkene/Cycloalkane & & 0.56 & 0.01 \\
\hline 63 & Unknown C11 Alkene/Cycloalkane & & 0.12 & 0.001 \\
\hline 64 & Octanenitrile ${ }^{4}$ & $124-12-9$ & 0.10 & 0.01 \\
\hline 65 & Unknown C11 Alkane & & 0.26 & 0.02 \\
\hline 66 & Unknown C̣11 Alkane & & 0.15 & 0.01 \\
\hline 67 & Unknown C11 Alkane & & 0.32 & 0.03 \\
\hline 68 & Unknown C11 Alkene/Cycloalkane & & 0.27 & 0.01 \\
\hline 69 & Unknown C11 Diene/Cycloalkene ${ }^{3}$ & & 0.07 & - \\
\hline 70 & $\begin{array}{l}\text { Naphthalene, decahydro-, } \\
\text { trans- }\end{array}$ & $493-02-7$ & 0.38 & 0.001 \\
\hline 71 & 1-Undecene & $821-95-4$ & 0.23 & 0.01 \\
\hline 72 & Unknown C11 Alkene/Cycloalkane & & 0.29 & 0.03 \\
\hline 73 & n-Undecane & $1120-21-4$ & 11.29 & 1.06 \\
\hline 74 & Octane, 4-methyl-3 & $2216-34-4$ & 0.07 & - \\
\hline 75 & Unknown C11 Alkene/Cycloalkane & & 0.44 & 0.05 \\
\hline 76 & Unknown C12 Alkane & & 0.21 & 0.02 \\
\hline 77 & Unknown C12 Alkane & & 0.42 & 0.04 \\
\hline 78 & Unknown C11 Diene/Cycloalkene & & 0.22 & 0.06 \\
\hline 79 & Naphthalene, methyl-decahydro & & 0.68 & 0.10 \\
\hline 80 & Cyclohexane, pentyl- & $4292-92-6$ & 0.52 & 0.06 \\
\hline 81 & Unknown C12 Alkane & & 0.40 & 0.04 \\
\hline 82 & Naphthalene, methyl-decahydro & & 0.89 & 0.08 \\
\hline
\end{tabular}


WHC-SD-WM-ER-459 Rev. 1

\begin{tabular}{|c|c|c|c|c|}
\hline $\begin{array}{c}\text { Cmpd } \\
\#\end{array}$ & Compound & $\begin{array}{c}\text { CAS }^{1} \\
\text { Number }\end{array}$ & $\begin{array}{l}\text { Average } \\
\left(\mathrm{mg} / \mathrm{m}^{3}\right)\end{array}$ & $\begin{array}{c}\text { Standard } \\
\text { Deviation } \\
\left(\mathrm{mg} / \mathrm{m}^{3}\right) \\
\end{array}$ \\
\hline 83 & Unknown C12 Alkane & & 0.43 & 0.04 \\
\hline 84 & Unknown C12 Alkane & & 0.26 & 0.03 \\
\hline 85 & Unknown Ketone & & 0.19 & 0.02 \\
\hline 86 & Unknown C12 Alkene/Cycloalkane & & 0.30 & 0.03 \\
\hline 87 & n-Dodecane & $112-40-3$ & 12.29 & 1.05 \\
\hline 88 & Undecane, 2,6-dimethyi- & $17301-23-4$ & 2.56 & 0.26 \\
\hline 89 & Unknow̄n C13 Alkene/Cycloalkane & & 0.10 & 0.01 \\
\hline 90 & Unknown C13 Alkene/Cycloalkane & & 1.03 & 0.11 \\
\hline 91 & Unknown C12 Alkane & & 0.56 & 0.05 \\
\hline 92 & Unknown C13 Alkene/Cycloalkane ${ }^{4}$ & & 0.39 & 0.04 \\
\hline 93 & Unknown C13 Alkane ${ }^{3}$ & & 0.46 & - \\
\hline 94. & Unknown C13 Alkane ${ }^{3}$ & & 0.17 & - \\
\hline 95 & Unknown Alkane ${ }^{4}$ & & 0.17 & 0.02 \\
\hline 96 & Octane, 2,3,7-trimethyl- & $62016-34-6$ & 2.51 & 0.24 \\
\hline 97 & Unknown C13 Alkene/Cycloalkane & & 0.10 & $<0.01$ \\
\hline 98 & n-Tridecane & $629-50-5$ & 12.05 & 0.64 \\
\hline 99 & Unknown C14 Alkene/Cycloalkane & & 0.39 & 0.05 \\
\hline 100 & Unknown Alkane & & 0.37 & 0.04 \\
\hline 101 & Unknown C13 Diene/Cycloalkene ${ }^{4}$ & & 0.096 & 0.005 \\
\hline 102 & Unknown C13 Alkene/Cycloalkane & & 0.56 & 0.06 \\
\hline 103 & Unknown C15 Alkene/Cycloalkane ${ }^{3}$ & & 0.10 & - \\
\hline 104 & Unknown Alkane 4 & & 0.10 & 0.01 \\
\hline 105 & Unknown C15 Alkane & & 1.29 & 0.08 \\
\hline 106 & n-Tetradecane & $629-59-4$ & 4.44 & 0.16 \\
\hline 107 & Unknown Alkane ${ }^{4}$ & & 0.13 & $<0.01$ \\
\hline 108 & Unknown C15 Alkene/Cycloalkane ${ }^{3}$ & & 0.11 & - \\
\hline 109 & Unknown C15 Alkene/Cycloalkane ${ }^{3}$ & & 0.13 & - \\
\hline 110 & Unknown Alkane & & 0.32 & 0.01 \\
\hline
\end{tabular}


WHC-SD-WM-ER-459 Rev.1

\begin{tabular}{|c|c|c|c|c|}
\hline$\underset{\#}{C m p d}$ & Compound & $\begin{array}{c}\mathrm{CAS}^{1} \\
\text { Number }\end{array}$ & $\begin{array}{l}\text { Average } \\
\left(\mathrm{mg} / \mathrm{m}^{3}\right)\end{array}$ & $\begin{array}{c}\text { Standard }{ }^{2} \\
\text { Deviation } \\
\left(\mathrm{mg} / \mathrm{m}^{3}\right)\end{array}$ \\
\hline 111 & n-Pentadecane & $629-62-9$ & 0.16 & 0.02 \\
\hline Sum of & entatively identified compounds: & & 108.7 & \\
\hline
\end{tabular}

$1 \mathrm{CAS}=$ Chemical Abstract Service.

2 When the analyte was detected in only 2 samples, the entry is the relative difference (i.e., their difference divided by 2).

3 Detected in only one sample.

4 Detected in only two samples. 


\section{WHC-SD-WM-ER-459 Rev.1}

Table 4-7

Tank C-102 Tentatively Identiffed Compounds in SUMMA ${ }^{\text {Th }}$ Samples Sorted Alphanumerically Analyses by Pacific Northwest Laboratory

\begin{tabular}{|c|c|c|c|c|}
\hline$\underset{\#}{\text { Cmpd }}$ & Compound & $\begin{array}{c}\mathrm{CAS}^{\dagger} \\
\text { Number }\end{array}$ & $\begin{array}{l}\text { Average } \\
\left(\mathrm{mg} / \mathrm{m}^{3}\right)\end{array}$ & $\begin{array}{c}\text { Standard }{ }^{2} \\
\text { Deviation } \\
\left(\mathrm{mg} / \mathrm{m}^{3}\right)\end{array}$ \\
\hline 11 & 1-Pentene & $109-67-1$ & 0.30 & 0.05 \\
\hline 35 & 1-Octene & $111-66-0$ & 0.23 & 0.01 \\
\hline 3 & 1-Propyne & $74-99-7$ & 0.60 & 0.02 \\
\hline 71 & 1-Undecene & $821-95-4$ & 0.23 & 0.01 \\
\hline 27 & 1.Heptene & $592-76-7$ & 0.34 & 0.002 \\
\hline 23 & 1-Butanol & $71-36-3$ & 27.82 & 3.56 \\
\hline 7 & 1-Butene & $106-98-9$ & 0.61 & 0.09 \\
\hline 17 & 1-Hexene & $592-41-6$ & 0.35 & 0.01 \\
\hline 9 & 1-Propene, 2-methyl- & $115-11-7$ & 0.12 & 0.02 \\
\hline 30 & 1-Heptanol & $53535-33-4$ & 0.30 & 0.01 \\
\hline 45 & 2-Heptanone, 6-methyl- & $928-68-7$ & 1.25 & 0.02 \\
\hline 44 & 2-Heptanone, 4-methyl- & $6137-06-0$ & 0.082 & 0.002 \\
\hline 13 & 2-Pentanone & $107-87-9$ & $<0.04$ & - \\
\hline 14 & 2-Pentene & $109-68-2$ & $<0.03$ & - \\
\hline 33 & 2-Hexanone & $591-78-6$ & 0.73 & 0.01 \\
\hline 25 & 2-Pentanone & $107-87-9$ & 1.61 & 0.03 \\
\hline 37 & 2-Hexanone, 5-methyl- & $110-12-3$ & 0.19 & 0.01 \\
\hline 52 & 2-Octanone & $111-13-7$ & 0.66 & 0.01 \\
\hline 40 & 2-Heptanone & $110-43-0$ & 0.86 & 0.06 \\
\hline 39 & $\begin{array}{l}\text { 2-Furanmethanol, } \\
\text { tetrahydro- }{ }^{3}\end{array}$ & $97-99-4$ & 0.074 & 0.01 \\
\hline 28 & 2-Pentanone, 3-methyl- & $565-61-7$ & 0.083 & 0.002 \\
\hline 22 & 2-Butanone, 3-methyl- & $563-80-4$ & 0.13 & 0.003 \\
\hline 20 & 3-Buten-1-o/ & $627-27-0$ & 0.08 & - \\
\hline 48 & 4-Octanone & $589-63-9$ & 0.11 & 0.004 \\
\hline 16 & Butanal & $123-72-8$ & 0.77 & 0.03 \\
\hline
\end{tabular}




\begin{tabular}{|c|c|c|c|c|}
\hline$\underset{\#}{\text { Cmpd }}$ & Compound & $\begin{array}{c}\text { CAS }^{1} \\
\text { Number }\end{array}$ & $\begin{array}{l}\text { Average } \\
\left(\mathrm{mg} / \mathrm{m}^{3}\right)\end{array}$ & $\begin{array}{c}\text { Standard } \\
\text { Deviation } \\
\left(\mathrm{mg} / \mathrm{m}^{3}\right) \\
\end{array}$ \\
\hline 21 & Butanal, 3-methyl-3 & $590-86-3$ & 0.08 & - \\
\hline 46 & Cyclohexane, propyl- & $1678-92-8$ & 0.11 & 0.004 \\
\hline 53 & Cyclohexane, 1,1,2,3-tetramethyl- & $6783-92-2$ & 0.20 & 0.003 \\
\hline 80 & Cyciohexane, pentyl- & $4292-92-6$ & 0.52 & 0.06 \\
\hline 4 & Cyclopropane & $75-19-4$ & 0.25 & 0.01 \\
\hline 5 & Ethanal (acetaldehyde) & $75-07-0$ & 0.68 & 0.13 \\
\hline 10 & Ethanol & $64-17-5$ & 0.16 & 0.02 \\
\hline 41 & Heptanal & $111-71-7$ & 0.39 & 0.01 \\
\hline 32 & Heptane, 2-methyl- & $592-27-8$ & 0.24 & 0.01 \\
\hline 47 & Heptanenitrile & $629-08-3$ & 0.41 & 0.02 \\
\hline 34 & Hexanal & $66-25-1$ & 0.50 & 0.02 \\
\hline 38 & Hexanenitrile & $628-73-9$ & 0.14 & 0.003 \\
\hline 6 & Methanol (methyl alcohol) & $67-56-1$ & $<0.01$ & - \\
\hline 8 & n-Butane & $106-97-8$ & 1.09 & 0.37 \\
\hline 87 & n-Dodecane & $112-40-3$ & 12.29 & 1.05 \\
\hline 42 & n-Nonane & $111-84-2$ & 0.87 & 0.02 \\
\hline 36 & n-Octane & $111-65-9$ & 1.22 & 0.03 \\
\hline 111 & n-Pentadecane & $629-62-9$ & 0.16 & 0.02 \\
\hline 12 & n-Pentane & $109-66-0$ & 0.62 & 0.10 \\
\hline 106 & n-Tetradecane & $629-59-4$ & 4.44 & 0.16 \\
\hline 98 & n-Tridecane & $629-50-5$ & 12.05 & 0.64 \\
\hline 73 & n-Undecane & $1120-21-4$ & 11.29 & 1.06 \\
\hline 70 & $\begin{array}{l}\text { Naphthalene, decahydro-, } \\
\text { trans- }\end{array}$ & $493-02-7$ & 0.38 & 0.001 \\
\hline 79 & Naphthalene, methyl-decahydro & & 0.68 & 0.10 \\
\hline 82 & Naphthalene, methyl-decahydro & & 0.89 & 0.08 \\
\hline 18 & Nitric acid, ethyl ester & $625-58-1$ & 0.18 & 0.01 \\
\hline 24 & Nitric acid, 1-methylethyl ester & $1712-64-7$ & 0.15 & 0.01 \\
\hline 43 & Nitric acid, pentyl ester & $1002-16-0$ & 0.16 & 0.01 \\
\hline
\end{tabular}


WHC-SD-WM-ER-459 Rev.1

\begin{tabular}{|c|c|c|c|c|}
\hline$\underset{\#}{\text { Cmpd }}$ & Compound & $\begin{array}{c}\mathrm{CAS}^{1} \\
\text { Number }\end{array}$ & $\begin{array}{l}\text { Average } \\
\left(\mathrm{mg} / \mathrm{m}^{3}\right)\end{array}$ & $\begin{array}{c}\text { Standard } \\
\text { Deviation } \\
\left(\mathrm{mg} / \mathrm{m}^{3}\right)\end{array}$ \\
\hline 57 & Nitric acid, hexyl ester & 20633-11-8 & 0.079 & 0.002 \\
\hline 19 & Nitrous acid, butyl ester ${ }^{4}$ & $544-16-1$ & 0.09 & - \\
\hline 54 & Octanal & $124-13-0$ & 0.25 & 0.03 \\
\hline 74 & Octane, 4-methyl- ${ }^{3}$ & $2216-34-4$ & 0.07 & - \\
\hline 96 & Octane, 2,3,7-trimethyl- & $62016-34-6$ & 2.51 & 0.24 \\
\hline 64 & Octanènitrile ${ }^{4}$ & $124-12-9$ & 0.10 & 0.01 \\
\hline 26 & Pentanal & $110-62-3$ & 0.90 & 0.01 \\
\hline 15 & Pentane, 2-methyl- & $107-83-5$ & 0.22 & 0.004 \\
\hline 29 & Pentanenitrile & $110-59-8$ & 0.16 & 0.001 \\
\hline 2 & Propane & $74-98-6$ & 0.64 & 0.02 \\
\hline 1 & Propene & $115-07-1$ & 1.36 & 0.05 \\
\hline 88 & Undecane, 2,6-dimethyl- & $17301-23-4$ & 2.56 & 0.26 \\
\hline 31 & Unknown Alkyl Nitrate & & 0.083 & 0.004 \\
\hline 49 & Unknown C10 Alkane & & 0.17 & 0.01 \\
\hline 50 & Unknown C10 Alkane & & 0.16 & 0.01 \\
\hline 51 & Unknown Alkane ${ }^{3}$ & & 0.15 & - \\
\hline 55 & Unknown C9 Alkene/Cycioalkane & & 0.21 & 0.003 \\
\hline 56 & Unknown C10 Alkene/Cycloalkane ${ }^{4}$ & & 0.10 & 0.01 \\
\hline 58 & Unknown C10 Alkene/Cycloalkane ${ }^{4}$ & & 0.067 & $<0.01$ \\
\hline 59 & Unknown C10 Alkene/Cycloalkane & & 0.074 & 0.007 \\
\hline 60 & Unknown C11 Alkane & & 0.79 & 0.02 \\
\hline 61 & Unknown C11 Alkane & & 0.21 & 0.01 \\
\hline 62 & Unknown C10 Alkene/Cycloalkane & & 0.56 & 0.01 \\
\hline 63 & Unknown C11 Alkene/Cycloalkane & & 0.12 & 0.001 \\
\hline 65 & Unknown C11 Alkane & & 0.26 & 0.02 \\
\hline 66 & Unknown C11 Alkane & & 0.15 & 0.01 \\
\hline 67 & Unknown C11 Alkane & & 0.32 & 0.03 \\
\hline 68 & Unknown C11 Alkene/Cycloalkane & & 0.27 & 0.01 \\
\hline
\end{tabular}




\begin{tabular}{|c|c|c|c|c|}
\hline $\begin{array}{c}\text { Cmpd } \\
\#\end{array}$ & Compound & $\begin{array}{l}\text { CAS }^{1} \\
\text { Number }\end{array}$ & $\begin{array}{l}\text { Average } \\
\left(\mathrm{mg} / \mathrm{m}^{3}\right)\end{array}$ & $\begin{array}{c}\text { Standard }{ }^{2} \\
\text { Deviation } \\
\left(\mathrm{mg} / \mathrm{m}^{3}\right)\end{array}$ \\
\hline 69 & Unknown C11 Diene/Cycloalkene ${ }^{3}$ & & 0.07 & - \\
\hline 72 & Unknown C11 Alkene/Cycloalkane & & 0.29 & $0.0 \dot{3}$ \\
\hline 75 & Unknown C11 Alkene/Cycloalkane & & 0.44 & 0.05 \\
\hline 76 & Unknown C12 Alkane & & 0.21 & 0.02 \\
\hline 77 & Unknown C12 Alkane & & 0.42 & 0.04 \\
\hline 78 & Unknown C11 Diene/Cycloalkene & & 0.22 & 0.06 \\
\hline 81 & Unknown C12 Alkane & & 0.40 & 0.04 \\
\hline 83 & Unknown C12 Alkane & & 0.43 & 0.04 \\
\hline 84 & Unknown C12 Alkane & & 0.26 & 0.03 \\
\hline 85 & Unknown Ketone & & 0.19 & 0.02 \\
\hline 86 & Unknown C12 Alkene/Cycloalkane & & 0.30 & 0.03 \\
\hline 89 & Unknown C13 Alkene/Cycloalkane & & 0.10 & 0.01 \\
\hline 90 & Unknown C13 Alkene/Cycloalkane & & 1.03 & 0.11 \\
\hline 91 & Unknown C12 Alkane & & 0.56 & 0.05 \\
\hline 92 & Unknown C13 Alkene/Cycloalkane ${ }^{4}$ & & 0.39 & 0.04 \\
\hline 93 & Unknown C13 Alkane ${ }^{3}$ & & 0.46 & - \\
\hline 94 & Unknown C13 Alkane ${ }^{3}$ & & 0.17 & - \\
\hline 95 & Unknown Alkane ${ }^{4}$ & & 0.17 & 0.02 \\
\hline 97 & Unknown C13 Alkene/Cycloalkane ${ }^{4}$ & & 0.10 & $<0.01$ \\
\hline 99 & Unknown C14 Alkene/Cycloalkane & & 0.39 & 0.05 \\
\hline 100 & Unknown Alkane & & 0.37 & 0.04 \\
\hline 101 & Unknown C13 Diene/Cycloalkene ${ }^{4}$ & & 0.096 & 0.005 \\
\hline 102 & Unknown C13 Alkene/Cycloalkane & & 0.56 & 0.06 \\
\hline 103 & Unknown C15 Alkene/Cycioalkane ${ }^{3}$ & & 0.10 & - \\
\hline 104 & Unknown Alkane ${ }^{4}$ & & 0.10 & 0.01 \\
\hline 105 & Unknown C15 Alkane & & 1.29 & 0.08 \\
\hline 107 & Unknown Alkane ${ }^{4}$ & & 0.13 & $<0.01$ \\
\hline 108 & Unknown C15 Alkene/Cycloalkane ${ }^{3}$ & & 0.11 & - \\
\hline
\end{tabular}


WHC-SD-WM-ER-459 Rev.1

\begin{tabular}{clccc}
\hline \hline $\begin{array}{c}\text { Cmpd } \\
\#\end{array}$ & Compound & $\begin{array}{c}\text { CAS } \\
\text { Number }\end{array}$ & $\begin{array}{c}\text { Average } \\
\left(\mathrm{mg} / \mathrm{m}^{3}\right)\end{array}$ & $\begin{array}{c}\text { Standard } \\
\text { Deviation } \\
\left(\mathrm{mg} / \mathrm{m}^{3}\right)\end{array}$ \\
\hline \hline $109 \quad$ Unknown C15 Alkene/Cycloalkane & - \\
$110 \quad$ Unknown Alkane & 0.13 & - \\
\hline \hline Sum of tentatively identified compounds: & 0.32 & 0.01 \\
\hline \hline
\end{tabular}

$1 \mathrm{CAS}=$ Chemical Abstract Service.

2 When the analyte was detected in only 2 samples, the entry is the relative difference (i.e., their difference divided by 2 ).

3 Detected in only two samples.

4 Detected in only one sample. 
WHC-SD-WM-ER-459 Rev.1

Table 4-8

Tank C-102 Tentatively Identified Compounds in SUMMA ${ }^{\text {TM }}$ Samples Sorted by Estimated Concentration -. Analyses by Pacific Northwest Laboratory

\begin{tabular}{|c|c|c|c|c|}
\hline$\underset{\#}{\text { Cmpd }}$ & Compound & $\begin{array}{c}\mathrm{CAS}^{1} \\
\text { Number }\end{array}$ & $\begin{array}{l}\text { Average } \\
\left(\mathrm{mg} / \mathrm{m}^{3}\right)\end{array}$ & $\begin{array}{c}\text { Standard }{ }^{2} \\
\text { Deviation } \\
\left(\mathrm{mg} / \mathrm{m}^{3}\right)\end{array}$ \\
\hline 23 & 1-Butanol & $=71-36-3$ & 27.82 & 3.56 \\
\hline 87 & n-Dodecane & $112-40-3$ & 12.29 & 1.05 \\
\hline 98 & n-Tridecane & $629-50-5$ & 12.05 & 0.64 \\
\hline 73 & $\mathrm{n}$-Undecane & $1120-21-4$ & 11.29 & 1.06 \\
\hline 106 & n-Tetradecane & $629-59-4$ & 4.44 & 0.16 \\
\hline 88 & Undecane, 2,6-dimethyl- & $17301-23-4$ & 2.56 & 0.26 \\
\hline 96 & Octane, 2,3,7-trimethyl- & $62016-34-6$ & 2.51 & 0.24 \\
\hline 25 & 2-Pentanone & $107-87-9$ & 1.61 & 0.03 \\
\hline 1 & Propene & $115-07-1$ & 1.36 & 0.05 \\
\hline 105 & Unknown C15 Alkane & & 1.29 & 0.08 \\
\hline 45 & 2-Heptanone, 6-methyl- & $928-68-7$ & 1.25 & 0.02 \\
\hline 36 & n-Octane & $111-65-9$ & 1.22 & 0.03 \\
\hline 8 & n-Butane & $106-97-8$ & 1.09 & 0.37 \\
\hline 90 & Unknown C13 Alkene/Cycloalkane & & 1.03 & 0.11 \\
\hline 26 & Pentanal & $110-62-3$ & 0.90 & 0.01 \\
\hline 82 & Naphthalene, methyl-decahydro & & 0.89 & 0.08 \\
\hline 42 & n-Nonane & $111-84-2$ & 0.87 & 0.02 \\
\hline 40 & 2-Heptanone & $110-43-0$ & 0.86 & 0.06 \\
\hline 60 & Unknown C11 Alkane & & 0.79 & 0.02 \\
\hline 16 & Butanal & $123-72-8$ & 0.77 & 0.03 \\
\hline 33 & 2-Hexanone & $591-78-6$ & 0.73 & 0.01 \\
\hline 79 & Naphthalene, methyl-decahydro- & & 0.68 & 0.10 \\
\hline 5 & Ethanal (acetaldehyde) & $75-07-0$ & 0.68 & 0.13 \\
\hline 52 & 2-Octanone & $111-13-7$ & 0.66 & 0.01 \\
\hline 2 & Propane & $74-98-6$ & 0.64 & 0.02 \\
\hline 12 & $\mathrm{n}$-Pentane & $109-66-0$ & 0.62 & 0.10 \\
\hline
\end{tabular}




\begin{tabular}{|c|c|c|c|c|}
\hline$\underset{\#}{\mathrm{Cmpd}}$ & Compound & $\begin{array}{c}\mathrm{CAS}^{1} \\
\text { Number }\end{array}$ & $\begin{array}{l}\text { Average } \\
\left(\mathrm{mg} / \mathrm{m}^{3}\right)\end{array}$ & $\begin{array}{c}\text { Standard }{ }^{2} \\
\text { Deviation } \\
\left(\mathrm{mg} / \mathrm{m}^{3}\right)\end{array}$ \\
\hline 7 & 1-Butene & $106-98-9$ & 0.61 & 0.09 \\
\hline 3 & 1-Propyne & $74-99-7$ & 0.60 & 0.02 \\
\hline 62 & Unknown C10 Alkene/Cycloalkane & & 0.56 & 0.01 \\
\hline 102 & Unknown C13 Alkene/Cycloalkane & & 0.56 & 0.06 \\
\hline 91 & Unknown C12 Alkane & & 0.56 & 0.05 \\
\hline 80 & Cyclohexane, pentyl- & $4292-92-6$ & 0.52 & 0.06 \\
\hline 34 & Hexanal & $66-25-1$ & 0.50 & 0.02 \\
\hline 93 & Unknown C13 Alkane ${ }^{3}$ & & 0.46 & - \\
\hline 75 & Unknown C11 Alkene/Cycloalkane & & 0.44 & 0.05 \\
\hline 83 & Unknown C12 Alkane & $\cdot$ & 0.43 & 0.04 \\
\hline 77 & Unknown C12 Alkane & & 0.42 & 0.04 \\
\hline 47 & Heptanenitrile & $629-08-3$ & 0.41 & 0.02 \\
\hline 81 & Unknown C12 Alkane & & 0.40 & 0.04 \\
\hline 92 & Unknown C13 Alkene/Cycloalkane ${ }^{4}$ & & 0.39 & 0.04 \\
\hline 41 & Heptanal & $111-71-7$ & 0.39 & 0.01 \\
\hline 99 & Unknown C14 Alkene/Cycloalkane & & 0.39 & 0.05 \\
\hline 70 & $\begin{array}{l}\text { Naphthalene, decahydro-, } \\
\text { trans- }\end{array}$ & $493-02-7$ & 0.38 & 0.001 \\
\hline 100 & Unknown Alkane & & 0.37 & 0.04 \\
\hline 17 & 1-Hexene & $592-41-6$ & 0.35 & 0.01 \\
\hline 27 & 1-Heptene & $592-76-7$ & 0.34 & 0.002 \\
\hline 67 & Unknown C11 Alkane & & 0.32 & 0.03 \\
\hline 110 & Unknown Alkane & & 0.32 & 0.01 \\
\hline 30 & 1-Heptanol & $53535-33-4$ & 0.30 & 0.01 \\
\hline 11 & 1-Pentene & $109-67-1$ & 0.30 & 0.05 \\
\hline 86 & Unknown C12 Alkene/Cycloalkane & & 0.30 & 0.03 \\
\hline 72 & Unknown C11 Alkene/Cycloalkane & & 0.29 & 0.03 \\
\hline 68 & Unknown C11 Alkene/Cycloalkane & & 0.27 & 0.01 \\
\hline 65 & Unknown C11 Alkane & & 0.26 & 0.02 \\
\hline
\end{tabular}


WHHC-SD-WM-ER-459 ReV.1

\begin{tabular}{|c|c|c|c|c|}
\hline$\underset{\#}{\text { Cmpd }}$ & Compound & $\begin{array}{c}\text { CAS }^{1} \\
\text { Number }\end{array}$ & $\begin{array}{l}\text { Average } \\
\left(\mathrm{mg} / \mathrm{m}^{3}\right)\end{array}$ & $\begin{array}{c}\text { Standard }{ }^{2} \\
\text { Deviation } \\
\left(\mathrm{mg} / \mathrm{m}^{3}\right)\end{array}$ \\
\hline 84 & Unknown C12 Alkane & & 0.26 & 0.03 \\
\hline 54 & Octanal & $124-13-0$ & 0.25 & 0.03 \\
\hline 4 & Cyclopropane & $75-19-4$ & 0.25 & 0.01 \\
\hline 32 & Heptane, 2-methyl- & $592-27-8$ & 0.24 & 0.01 \\
\hline 71 & 1-Undecene & $821-95-4$ & 0.23 & 0.01 \\
\hline 35 & 1-Octene & $111-66-0$ & 0.23 & 0.01 \\
\hline 78 & Unknown C11 Diene/Cycloalkene & & 0.22 & 0.06 \\
\hline 15 & Pentane, 2-methyl- & $107-83-5$ & 0.22 & 0.004 \\
\hline 61 & Unknown C11 Alkane & & 0.21 & 0.01 \\
\hline 55 & Unknown C9 Alkene/Cycloalkane & & 0.21 & 0.003 \\
\hline 76 & Unknown C12 Alkane & & 0.21 & 0.02 \\
\hline 53 & Cyclohexane, 1,1,2,3-tetramethyl- & $6783-92-2$ & 0.20 & 0.003 \\
\hline 85 & Unknown Ketone & & 0.19 & 0.02 \\
\hline 37 & 2-Hexanone, 5-methyl- & $110-12-3$ & 0.19 & 0.01 \\
\hline 18 & Nitric acid, ethyl ester & $625-58-1$ & 0.18 & 0.01 \\
\hline 95 & Unknown Alkane ${ }^{4}$ & & 0.17 & 0.02 \\
\hline 49 & Unknown C10 Alkane & & 0.17 & 0.01 \\
\hline 94 & Unknown C13 Alkane ${ }^{3}$ & & 0.17 & - \\
\hline 29 & Pentanenitrile & $110-59-8$ & 0.16 & 0.001 \\
\hline 43 & Nitric acid, pentyl ester & $1002-16-0$ & 0.16 & 0.01 \\
\hline 50 & Unknown C10 Alkane & & 0.16 & 0.01 \\
\hline 10 & Ethanol & $64-17-5$ & 0.16 & 0.02 \\
\hline 111 & n-Pentadecane & $629-62-9$ & 0.16 & 0.02 \\
\hline 24 & Nitric acid, 1-methylethyl ester & $1712-64-7$ & 0.15 & 0.01 \\
\hline 66 & Unknown C11 Alkane & & 0.15 & 0.01 \\
\hline 51 & Unknown Alkane $^{3}$ & & 0.15 & - \\
\hline 38 & Hexanenitrile & $628-73-9$ & 0.14 & 0.003 \\
\hline 107 & Unknown Alkane ${ }^{4}$ & & 0.13 & $<0.01$ \\
\hline
\end{tabular}




\begin{tabular}{|c|c|c|c|c|}
\hline$\underset{\#}{\text { Cmpd }}$ & Compound & $\begin{array}{c}\mathrm{CAS}^{1} \\
\text { Number }\end{array}$ & $\begin{array}{l}\text { Average } \\
\left(\mathrm{mg} / \mathrm{m}^{3}\right)\end{array}$ & $\begin{array}{c}\text { Standard } \\
\text { Deviation } \\
\left(\mathrm{mg} / \mathrm{m}^{3}\right) \\
\end{array}$ \\
\hline 109 & Unknown C15 Alkene/Cycloalkane ${ }^{3}$ & & 0.13 & - \\
\hline 22 & 2-Butanone, 3-methyl- & $563-80-4$ & 0.13 & 0.003 \\
\hline 9 & 1-Propene, 2-methyl- & $115-11-7$ & 0.12 & 0.02 \\
\hline 63 & Unknown C11 Alkene/Cycloalkane & & 0.12 & 0.001 \\
\hline 108 & Unknown C15 Alkene/Cycloalkane ${ }^{3}$ & & 0.11 & - \\
\hline $48^{\circ}$ & 4-Octanone & $589-63-9$ & 0.11 & 0.004 \\
\hline 46 & Cyclohexane, propyi- & $1678-92-8$ & 0.11 & 0.004 \\
\hline 89 & Unknown C13 Alkene/Cycloalkane & & 0.10 & 0.01 \\
\hline 103 & Unknown C15 Alkene/Cycloalkane ${ }^{3}$ & & 0.10 & - \\
\hline 56 & Unknown C10 Alkene/Cycloalkane ${ }^{4}$ & & 0.10 & 0.01 \\
\hline 64 & Octanenitrile ${ }^{4}$ & $124-12-9$ & 0.10 & 0.01 \\
\hline 104 & Unknown Alkane ${ }^{4}$ & & 0.10 & 0.01 \\
\hline 97 & Unknown C13 Alkene/Cycloalkane ${ }^{4}$ & & 0.10 & $<0.01$ \\
\hline 101 & Unknown C13 Diene/Cycloalkene ${ }^{4}$ & & 0.096 & 0.005 \\
\hline 19 & Nitrrous acid, butyl ester ${ }^{3}$ & $544-16-1$ & 0.09 & - \\
\hline 28 & 2-Pentanone, 3-methyl- & $565-61-7$ & 0.083 & 0.002 \\
\hline 31 & Unknown Alkyl Nitrate & & 0.083 & 0.004 \\
\hline 44 & 2-Heptanone, 4-methyl- & $6137-06-0$ & 0.082 & 0.002 \\
\hline 21 & Butanal, 3-methyl-3 & $590-86-3$ & 0.08 & - \\
\hline 20 & 3-Buten-1-o/ & $627-27-0$ & 0.08 & - \\
\hline 57 & Nitric acid, hexyl ester & $20633-11-8$ & 0.079 & 0.002 \\
\hline 39 & $\begin{array}{l}\text { 2-Furanmethanol, } \\
\text { tetrahydro-4 }\end{array}$ & $97-99-4$ & 0.074 & 0.01 \\
\hline 59 & Unknown C10 Alkene/Cycloalkane & & 0.074 & 0.007 \\
\hline 69 & Unknown C11 Diene/Cycloalkene ${ }^{3}$ & & 0.07 & - \\
\hline 74 & Octane, 4-methyl- ${ }^{3}$ & $2216-34-4$ & $\cdot 0.07$ & - \\
\hline 58 & Unknown C10 Alkene/Cycloalkane ${ }^{4}$ & & 0.067 & $<0.01$ \\
\hline 6 & Methanol (methyl alcohol) & $67-56-1$ & $<0.01$ & - \\
\hline 13 & 2-Pentanone & $107-87-9$ & $<0.04$ & - \\
\hline
\end{tabular}


WHC-SD-WM-ER-459 Rev.1

\begin{tabular}{clccc}
\hline \hline $\begin{array}{c}\text { Cmpd } \\
\#\end{array}$ & Compound & $\begin{array}{c}\mathrm{CAS}^{1} \\
\text { Number }\end{array}$ & $\begin{array}{c}\text { Average } \\
\left(\mathrm{mg} / \mathrm{m}^{3}\right)\end{array}$ & $\begin{array}{c}\text { Standard } \\
\text { Deviation } \\
\left(\mathrm{mg} / \mathrm{m}^{3}\right)\end{array}$ \\
\hline $14 \quad$ 2-Pentene & $109-68-2$ & $<0.03$ & - \\
\hline \hline Sum of tentatively identified compounds: & & 108.7 \\
\hline \hline
\end{tabular}

$1 \mathrm{CAS}=$ Chemical Abstract Service.

2 When the analyte was detected in only 2 samples, the entry is the relative difference (i.e., their difference divided by 2 ).

3 Detected in only one sample.

4 Detected in only two samples. 
WHC-SD-WM-ER-459 ReV.1

Table 4-9

Tank C-102 Tentatively Identified Organic Compounds in TST Samples

in Order of Chromatographic Elution --

Analyses by Oak Ridge National Laboratory

\begin{tabular}{|c|c|c|c|c|}
\hline$\underset{\#}{\text { Cmpd }}$ & Compound & $\begin{array}{l}\text { CAS }^{1} \\
\text { Number }\end{array}$ & $\begin{array}{l}\text { Average } \\
\left(\mathrm{mg} / \mathrm{m}^{3}\right)\end{array}$ & $\begin{array}{c}\text { Standard } \\
\text { Deviation } \\
\left(\mathrm{mg} / \mathrm{m}^{3}\right)\end{array}$ \\
\hline 1 & Methane, trichlorofluoro- & $75-69-4$ & 0.51 & 0.88 \\
\hline 2 & 2-Butanone & $78-93-3$ & 0.55 & 0.95 \\
\hline 3 & Furan, tetrahydro & $109-99-9$ & 0.89 & 0.79 \\
\hline 4 & $2(3 \mathrm{H})$-furanone, dihydro-3,5-dimethyl- & $5145-01-7$ & 0.24 & 0.22 \\
\hline 5 & $\begin{array}{l}\text { Cyclobutane, 1,2-diethyl-, } \\
\text { trans- \& cis- }\end{array}$ & & 0.15 & 0.27 \\
\hline 6 & Cyclopropane, propyl- & $2415-72-7$ & 0.11 & 0.19 \\
\hline 7 & Benzene, ethyl- & $100-41-4$ & 0.090 & 0.155 \\
\hline 8 & Heptanal & $111-71-7$ & 0.10 & 0.17 \\
\hline 9 & Xylene & $1330-20-7$ & 0.40 & 0.39 \\
\hline 10 & Styrene & $100-42-5$ & 0.11 & 0.19 \\
\hline 11 & Xylene & $1330-20-7$ & 0.12 & 0.21 \\
\hline 12 & C8-Aikanone & & 0.82 & 0.34 \\
\hline 13 & 1,1,2,3-tetramethylcyclohexane & $6783-92-2$ & 0.22 & 0.20 \\
\hline 14 & Nonane, 4-methyl- & $17301-94-9$ & 0.12 & 0.20 \\
\hline 15 & 3-Buten-2-ol & $598-32-3$ & 1.1 & 0.48 \\
\hline 16 & Benzene, (1-methylethyl)- & $98-82-8$ & 0.079 & 0.136 \\
\hline 17 & Cyclohexane, 1-methyl-3-propyl- & $4291-80-9$ & 0.20 & 0.17 \\
\hline 18 & 2-Decene, (E)- & $20063-97-2$ & 0.14 & 0.13 \\
\hline 19 & Cyclohexane, (3-methyl-pentyl)- & $61142-38-9$ & 0.11 & 0.19 \\
\hline 20 & $\begin{array}{l}\text { Cyclohexane, 1,5-diethyl- } \\
\text { 2,3-dimethyl }\end{array}$ & $74663-66-4$ & 0.095 & 0.165 \\
\hline 21 & Nonane, 2,6-dimethyl- & $17302-28-2$ & 1.1 & 0.2 \\
\hline 22 & Benzene, 1-propenyl- & $637-50-3$ & 0.21 & 0.18 \\
\hline 23 & 4,5-Nonadiene & $821-74-9$ & 0.10 & 0.17 \\
\hline 24 & Cyclohexane, (1-methylpropyl)- & $7058-01-7$ & 0.24 & 0.06 \\
\hline
\end{tabular}




\begin{tabular}{|c|c|c|c|c|}
\hline Cmpd & Compound & $\begin{array}{l}\text { CAS }^{1} \\
\text { Number }\end{array}$ & $\begin{array}{l}\text { Average } \\
\left(\mathrm{mg} / \mathrm{m}^{3}\right)\end{array}$ & $\begin{array}{c}\text { Standard } \\
\text { Deviation } \\
\left(\mathrm{mg} / \mathrm{m}^{3}\right) \\
\end{array}$ \\
\hline 25 & 1,1-dimethyl-2-propylcyclohexane & & 0.30 & 0.03 \\
\hline 26 & Decane, 5-methyl- & $13151-35-4$ & 0.44 & 0.04 \\
\hline 27 & Decane, 4-methyl- & $2847-72-5$ & 0.34 & 0.08 \\
\hline 28 & Decane, 2-methyl- & $6975-98-0$ & 1.0 & 0.2 \\
\hline 29 & Naphthalene, decahydro-, trans- & $493-02-7$ & 0.53 & 0.10 \\
\hline 30 & Decane, 3-methyl- & $13151-34-3$ & 0.53 & 0.03 \\
\hline 31 & Benzene, 1-methyl-2-propyl- & $1074-17-5$ & 0.14 & 0.25 \\
\hline 32 & 4-Nonanone & $4485-09-0$ & 0.13 & 0.23 \\
\hline 33 & C4-benzene \& others & & 0.14 & 0.24 \\
\hline 34 & 5-Undecene & $4941-53-1$ & 0.44 & 0.01 \\
\hline 35 & 2-Nonanone & $821-55-6$ & 1.0 & 0.1 \\
\hline 36 & 2-Decene, 4-methyl-, (Z) & $74630-30-1$ & 0.11 & 0.19 \\
\hline 37 & 5-Undecene, (E)- & $764-97-6$ & 0.18 & 0.32 \\
\hline 38 & t-Undecene, 4-methyl- & $74630-39-0$ & .0 .41 & 0.36 \\
\hline 39 & Cyclopropane, octyl- & $1472-09-9$ & 0.62 & 0.12 \\
\hline 40 & Undecane, 5-methyl- & $1632-70-8$ & 0.82 & 0.19 \\
\hline 41 & Naphthalene, decahydro-2-methyl- & $2958-76-1$ & 0.39 & 0.54 \\
\hline 42 & Undecane, 2,8-dimethyl- & $17301-25-6$ & 0.097 & 0.168 \\
\hline 43 & Undecane, 4,8-dimethyl- & $17301-33-6$ & 0.083 & 0.143 \\
\hline 44 & Undecane, 3,8-dimethyl- & $17301-30-3$ & 2.0 & 0.7 \\
\hline 45 & Mixture & & 0.11 & 0.20 \\
\hline 46 & Benzene, (2-methyl-2-propenyl)- & $3290-53-7$ & 0.099 & 0.171 \\
\hline 47 & 1-Dodecene & $112-41-4$ & 0.14 & 0.13 \\
\hline 48 & 5-Undecene, 7-methyl- (E)- & $74630-66-3$ & 0.12 & 0.21 \\
\hline 49 & 3-Undecene, 2-methyl-, (Z)- & $74630-48-1$ & 1.1 & 1.7 \\
\hline 50 & Methyldecahydronaphthalene & & 3.1 & 0.5 \\
\hline 51 & 6-Methylundecane & $17302-33-9$ & 1.8 & 1.3 \\
\hline 52 & Undecane, 4-methyl- & $2980-69-0$ & 1.1 & 0.4 \\
\hline
\end{tabular}




\begin{tabular}{|c|c|c|c|c|}
\hline$\underset{\#}{\text { Cmpd }}$ & Compound & $\begin{array}{l}\text { CAS }^{1} \\
\text { Number }\end{array}$ & $\begin{array}{l}\text { Average } \\
\left(\mathrm{mg} / \mathrm{m}^{3}\right)\end{array}$ & $\begin{array}{c}\text { Standard } \\
\text { Deviation } \\
\left(\mathrm{mg} / \mathrm{m}^{3}\right) \\
\end{array}$ \\
\hline 53 & Undecane, 2-methyl- & $7045-71-8$ & 2.3 & 1.1 \\
\hline 54 & Benzene, pentyl- & $538-68-1$ & 0.46 & 0.48 \\
\hline 55 & Undecane, 3-methyl- & $1002-43-3$ & 1.2 & 0.6 \\
\hline 56 & 4-Undecene, 4-methyl- & $61142-40-3$ & 0.99 & 0.64 \\
\hline 57 & Undecane, 3-methyl- & $1002-43-3$ & 0.16 & 0.28 \\
\hline 58 & C13-Alkane & . & 0.25 & 0.43 \\
\hline 59 & Cyclododecane & $294-62-2$ & 1.3 & 0.2 \\
\hline 60 & Naphthalene, decahydro-1,2-dimethyl- & $3604-14-6$ & 0.71 & 0.18 \\
\hline 61 & 4-Dodecene, (E)- & $7206-15-7$ & 0.30 & 0.12 \\
\hline 62 & Undecane, 2,4-dimethyl- & $17312-80-0$ & 0.046 & 0.079 \\
\hline 63 & Undecane, 2,6-dimethyl- & $17301-23-4$ & 3.4 & 0.2 \\
\hline 64 & Undecane, 4,7-dimethyi- & $17301-32-5$ & 0.43 & 0.05 \\
\hline 65 & $\begin{array}{l}\text { Dimethyl-decahydro naphthalene } \\
+ \text { others }\end{array}$ & & 0.31 & 0.27 \\
\hline 66 & 4-Undecene, 5-methyl- (Z)- & $74630-69-6$ & 0.045 & 0.077 \\
\hline 67 & Undecane, 2,10-dimethyl- \& others & & 0.14 & 0.24 \\
\hline 68 & Cycopentane, 1-pentyl-2-propyl- & $62199-51-3$ & 0.078 & 0.135 \\
\hline 69 & $\begin{array}{l}\text { Cyciohexane, 2-butyl-1, } \\
\text { 1,3-trimethyl- }\end{array}$ & $54676-39-0$ & 1.7 & 0.2 \\
\hline 70 & Undecane, 5-ethyl- & $17453-94-0$ & 0.19 & 0.05 \\
\hline 71 & 3-Hexadecyne & $61886-62-2$ & 0.25 & 0.01 \\
\hline 72 & Cyclohexane, (4-methylpentyi)- & $61142-20-9$ & 0.84 & 0.06 \\
\hline 73 & Dodecane, 4-methyi- & $6117-97-1$ & 0.78 & 0.06 \\
\hline 74 & Dodecane, 2-methyl- & $1560-97-0$ & 1.5 & 0.1 \\
\hline 75 & $\begin{array}{l}\text { 2-Hexanone, 3-cyclo- } \\
\text { hexyliden-4-ethyl- }\end{array}$ & & 0.18 & 0.16 \\
\hline 76 & Dodecane, 4,6-dimethyl- & $61141-72-8$ & 3.8 & 0.4 \\
\hline 77 & $\begin{array}{l}\text { 2-Butenoic acid, } \\
\text { 2-propenyl ester \& others }\end{array}$ & & 0.27 & 0.48 \\
\hline 78 & Benzene, (1-methyipentyl)- & $6031-02-3$ & 0.15 & 0.26 \\
\hline
\end{tabular}


WHC-SD-WM-ER-459 Rev.1

\begin{tabular}{|c|c|c|c|c|}
\hline$\underset{\#}{\text { Cmpd }}$ & Compound & $\begin{array}{l}\text { CAS' }^{\prime} \\
\text { Number }\end{array}$ & $\begin{array}{l}\text { Average } \\
\left(\mathrm{mg} / \mathrm{m}^{3}\right)\end{array}$ & $\begin{array}{c}\text { Standard } \\
\text { Deviation } \\
\left(\mathrm{mg} / \mathrm{m}^{3}\right)\end{array}$ \\
\hline 79 & Trimethyldecahydronaphthalene & & 0.48 & 0.09 \\
\hline 80 & 3-Undecanone & $2216-87-7$ & 0.13 & 0.23 \\
\hline 81 & 6-Tridecane, 7-methyl- & $24949-42-6$ & 1.1 & 0.1 \\
\hline 82 & Undecane, 3,8-dimethyl- & $17301-30-3$ & 0.055 & 0.096 \\
\hline 83 & Alkane & & 0.16 & 0.16 \\
\hline 84 & Heptane, 3-ethyl-5-methyl- & $52896-90-9$ & 0.19 & 0.33 \\
\hline 85 & Alkane & & 0.10 & 0.17 \\
\hline 86 & Decane, 6-ethyl-2-methyl- & $62108-21-8$ & 0.37 & 0.63 \\
\hline 87 & Undecane, 5-ethyl- & $17453-94-0$ & 0.48 & 0.45 \\
\hline 88 & $\begin{array}{l}\text { Cyclooctane, 1-methylpropyl- } \\
\text { and others }\end{array}$ & & 0.14 & 0.12 \\
\hline 89 & Cyclooctane, butyl- & $16538-93-5$ & 0.055 & 0.096 \\
\hline 90 & C4-Cyclohexane & & 0.095 & 0.165 \\
\hline 91 & C12-alkene and C7-benzene & & 0.19 & 0.16 \\
\hline 92 & C8-cyclohexane & & 0.41 & 0.29 \\
\hline 93 & C14-alkene & & 0.32 & 0.14 \\
\hline 94 & C7-Cyclohexane & & 0.93 & 0.06 \\
\hline 95 & Tridecane, 4-methyl- & $26730-12-1$ & 0.51 & 0.11 \\
\hline 96 & Dodecane, 3-methyl- & $17312-57-1$ & 0.29 & 0.51 \\
\hline 97 & Tridecane, 2-methyl- & $1560-96-9$ & 0.70 & 0.22 \\
\hline 98 & C8-Cyclohexene & & 0.30 & 0.26 \\
\hline 99 & 5-Undecanone, 2-methyl- & $50639-02-6$ & 0.13 & 0.22 \\
\hline 100 & Dodecane, 2,7,10-trimethyl- & $74645-98-0$ & 2.6 & 0.2 \\
\hline 101 & Heptane, 2-phenyl- & $2132-84-5$ & 0.24 & 0.27 \\
\hline 102 & C8-Cyclohexane & & 0.043 & 0.074 \\
\hline 103 & 3-Dodecanone & $1534-27-6$ & 0.35 & 0.12 \\
\hline 104 & Tetradecane & $629-59-4$ & 4.5 & 1.8 \\
\hline 105 & Tridecane, 4,8-dimethyl- & $55030-62-1$ & 0.29 & 0.51 \\
\hline 106 & $1,1^{\prime}$-biphenyl & $92-52-4$ & 0.92 & 0.86 \\
\hline
\end{tabular}




\begin{tabular}{|c|c|c|c|c|}
\hline$\underset{\#}{\text { Cmpd }}$ & Compound & $\begin{array}{l}\text { CAS }^{1} \\
\text { Number }\end{array}$ & $\begin{array}{l}\text { Average } \\
\left(\mathrm{mg} / \mathrm{m}^{3}\right)\end{array}$ & $\begin{array}{l}\text { Standard } \\
\text { Deviation } \\
\left(\mathrm{mg} / \mathrm{m}^{3}\right)\end{array}$ \\
\hline 107 & $\begin{array}{l}\text { 2-Hexenoic acid, } \\
\text { 2-hexenyl ester, }(E, E) \text { - }\end{array}$ & $54845-28-2$ & 0.052 & 0.090 \\
\hline 108 & 1,1-Bjphenyl,2-methyl- & $643-58-3$ & 0.48 & 0.57 \\
\hline 109 & $\begin{array}{l}\text { Benzene, } 1,1^{\prime} \text {-methylenebis- } \\
\text { and others }\end{array}$ & & 0.24 & 0.22 \\
\hline 110 & Tridecane, 4-methyl- & $26730-12-1$ & 0.087 & 0.151 \\
\hline 111 & C8-cyclohexane & & 0.068 & 0.117 \\
\hline 112 & Dodecane, 2,6,11-trimethyl- & $31295-56-4$ & 0.055 & 0.096 \\
\hline 113 & Tridecane, 4,8-dimethyl- & $55030-62-1$ & 0.047 & 0.081 \\
\hline 114 & Hexadecane & $544-76-3$ & 0.56 & 0.07 \\
\hline 115 & 2-Undecanone, 6,10-dimethyl- & $105-42-0$ & 0.059 & 0.103 \\
\hline 116 & Dimethyl-naphthalene & & 0.17 & 0.29 \\
\hline 117 & Benzene, (1-methylheptyi)- & $777-22-0$ & 0.031 & 0.053 \\
\hline 118 & Dodecane, 2-methyl-8-propyl- & $55045-07-3$ & 0.45 & 0.78 \\
\hline 119 & Pentadecane, 2-methyl- & $1560-93-6$ & 0.056 & 0.096 \\
\hline 120 & 5-Undecanone, 2-methyl- & $50639-02-6$ & 0.15 & 0.26 \\
\hline 121 & 3-Tridecanone & $1534-26-5$ & 0.21 & 0.14 \\
\hline 122 & Pentadecane & $629-62-9$ & 0.77 & 0.63 \\
\hline 123 & 1,1'-Biphenyl, 2-methyl- & $643-58-3$ & 0.067 & 0.116 \\
\hline 124 & 1,1'-Biphenyl, 2-methyl- & $643-58-3$ & 0.039 & 0.067 \\
\hline 125 & 9H-Fluorene & $86-73-7$ & 0.077 & 0.134 \\
\hline 126 & Benzenesulfonamide, N-butyl- & $3622-84-2$ & 0.23 & 0.04 \\
\hline \multicolumn{2}{|c|}{ Sum of tentatively identified compounds: } & & 67.03 & \\
\hline
\end{tabular}

$1 \mathrm{CAS}=$ Chemical Abstract Service. 
WHC-SD-WM-ER-459 Rev.1

Table 4-10

Tank C-102 Tentatively Identified Organic Compounds in TST Samples Sorted Alphanumerically -Analyses by Oak Ridge National Laboratory

\begin{tabular}{|c|c|c|c|c|}
\hline$\underset{\#}{\text { Cmpd }}$ & Compound & $\begin{array}{l}\text { CAS }^{1} \\
\text { Number }\end{array}$ & $\begin{array}{l}\text { Average } \\
\left(\mathrm{mg} / \mathrm{m}^{3}\right)\end{array}$ & $\begin{array}{c}\text { Standard } \\
\text { Deviation } \\
\left(\mathrm{mg} / \mathrm{m}^{3}\right)\end{array}$ \\
\hline 38 & 1-Undecene, 4-methyl- & $74630-39-0$ & 0.41 & 0.36 \\
\hline 47 & 1-Dodecene & $112-41-4$ & 0.14 & 0.13 \\
\hline 106 & 1,1'-biphenyl & $92-52-4$ & 0.92 & 0.86 \\
\hline 25 & 1,1-dimethyl-2-propylcyciohexane & & 0.30 & 0.03 \\
\hline 123 & 1,1'-Biphenyl, 2-methyl- & $643-58-3$ & 0.067 & 0.116 \\
\hline 108 & 1,1-Biphenyl,2-methyl- & $643-58-3$ & 0.48 & 0.57 \\
\hline 124 & 1,1'-Biphenyl, 2-methyl- & $643-58-3$ & 0.039 & 0.067 \\
\hline 13 & $1,1,2,3$-tetramethylcyclohexane & $6783-92-2$ & 0.22 & 0.20 \\
\hline 36 & 2-Decene, 4-methyl-, (Z) & $74630-30-1$ & 0.11 & 0.19 \\
\hline 35 & 2-Nonanone & $821-55-6$ & 1.0 & 0.1 \\
\hline 115 & 2-Undecanone, 6,10-dimethyl- & $105-42-0$ & 0.059 & 0.103 \\
\hline 75 & $\begin{array}{l}\text { 2-Hexanone, 3-cyclo- } \\
\text { hexyliden-4-ethyl- }\end{array}$ & & 0.18 & 0.16 \\
\hline 2 & 2-Butanone & $78-93-3$ & 0.55 & 0.95 \\
\hline 107 & $\begin{array}{l}\text { 2-Hexenoic acid, } \\
\text { 2-hexenyl ester, (E,E)- }\end{array}$ & $54845-28-2$ & 0.052 & 0.090 \\
\hline 77 & $\begin{array}{l}\text { 2-Butenoic acid, } \\
\text { 2-propenyl ester \& others }\end{array}$ & & 0.27 & 0.48 \\
\hline 18 & 2-Decene, (E)- & $20063-97-2$ & 0.14 & 0.13 \\
\hline 4 & 2(3H)-furanone, dihydro-3,5-dimethyl- & $5145-01-7$ & 0.24 & 0.22 \\
\hline 15 & 3-Buten-2-ol & $598-32-3$ & 1.1 & 0.48 \\
\hline 103 & 3-Dodecanone & $1534-27-6$ & 0.35 & 0.12 \\
\hline 49 & 3-Undecene, 2-methyl-, (Z)- & $74630-48-1$ & 1.1 & 1.7 \\
\hline 121 & 3-Tridecanone & $1534-26-5$ & 0.21 & 0.14 \\
\hline 80 & 3-Undecanone & $2216-87-7$ & 0.13 & 0.23 \\
\hline 71 & 3-Hexadecyne & $61886-62-2$ & 0.25 & 0.01 \\
\hline 32 & 4-Nonanone & $4485-09-0$ & 0.13 & 0.23 \\
\hline
\end{tabular}




\begin{tabular}{|c|c|c|c|c|}
\hline Cmpd & Compound & $\begin{array}{l}\text { CAS } \\
\text { Number }\end{array}$ & $\begin{array}{l}\text { Average } \\
\left(\mathrm{mg} / \mathrm{m}^{3}\right)\end{array}$ & $\begin{array}{c}\text { Standard } \\
\text { Deviation } \\
\left(\mathrm{mg} / \mathrm{m}^{3}\right)\end{array}$ \\
\hline 66 & 4-Undecene, 5-methyl- (Z)- & $74630-69-6$ & 0.045 & 0.077 \\
\hline 56 & 4-Undecene, 4-methyl- & $61142-40-3$ & 0.99 & 0.64 \\
\hline 61 & 4-Dodecene, (E)- & $7206-15-7$ & 0.30 & 0.12 \\
\hline 23 & 4,5-Nonadiené & $821-74-9$ & 0.10 & 0.17 \\
\hline 120 & 5-Undecanone, 2-methyl- & $50639-02-6$ & 0.15 & 0.26 \\
\hline 48 & 5-Undecene, 7-methyl- (E)- & $74630-66-3$ & 0.12 & 0.21 \\
\hline 37 & 5-Undecene, (E)- & $764-97-6$ & 0.18 & 0.32 \\
\hline 99 & 5-Undecanone, 2-methyl- & $50639-02-6$ & 0.13 & 0.22 \\
\hline 34 & 5-Undecene & $4941-53-1$ & 0.44 & 0.01 \\
\hline 81 & 6-Tridecane, 7-methyl- & $24949-42-6$ & 1.1 & 0.1 \\
\hline 51 & 6-Methylundecane & $17302-33-9$ & 1.8 & 1.3 \\
\hline 125 & 9H+Fiuorene & $86-73-7$ & 0.077 & 0.134 \\
\hline 83 & Alkane & & 0.16 & 0.16 \\
\hline 85 & Alkane & & 0.10 & 0.17 \\
\hline 7 & Benzene, ethyl- & $100-41-4$ & 0.090 & 0.155 \\
\hline 16 & Benzene, (1-methylethyl)- & $98-82-8$ & 0.079 & 0.136 \\
\hline 22 & Benzene, 1-propenyl- & $637-50-3$ & 0.21 & 0.18 \\
\hline 31 & Benzene, 1-methyl-2-propyi- & $1074-17-5$ & 0.14 & 0.25 \\
\hline 46 & Benzene, (2-methyl-2-propenyl)- & $3290-53-7$ & 0.099 & 0.171 \\
\hline 54 & Benzene, pentyl- & $538-68-1$ & 0.46 & 0.48 \\
\hline 78 & Benzene, (1-methylpentyl)- & $6031-02-3$ & 0.15 & 0.26 \\
\hline 109 & $\begin{array}{l}\text { Benzene, } 1,1 \text {-methylenebis- } \\
\text { and others }\end{array}$ & & 0.24 & 0.22 \\
\hline 117 & Benzene, (1-methylheptyl)- & $777-22-0$ & 0.031 & 0.053 \\
\hline 126 & Benzenesulfonamide, N-butyl- & $3622-84-2$ & 0.23 & 0.04 \\
\hline 91 & C12-alkene and C7-benzene & & 0.19 & 0.16 \\
\hline 58 & C13-Alkane & & 0.25 & 0.43 \\
\hline 93 & c14-alkene & & 0.32 & 0.14 \\
\hline 90 & C4-Cyclohexane & & 0.095 & 0.165 \\
\hline
\end{tabular}


WHC-SD-WM-ER-459 Rev.1

\begin{tabular}{|c|c|c|c|c|}
\hline$\underset{\#}{\text { Cmpd }}$ & Compound & $\begin{array}{l}\mathrm{CAS}^{\dagger} \\
\text { Number }\end{array}$ & $\begin{array}{l}\text { Average } \\
\left(\mathrm{mg} / \mathrm{m}^{3}\right)\end{array}$ & $\begin{array}{c}\text { Standard } \\
\text { Deviation } \\
\left(\mathrm{mg} / \mathrm{m}^{3}\right) \\
\end{array}$ \\
\hline 33 & C4-benzene \& others & & 0.14 & 0.24 \\
\hline 94 & C7-Cyclohexane & & 0.93 & 0.06 \\
\hline 12 & C8-Alkanone & & 0.82 & 0.34 \\
\hline 111 & C8-cyclohexane & & 0.068 & 0.117 \\
\hline 92 & C8-cyclohexane & & 0.41 & 0.29 \\
\hline 98 & C8-Cyclohexene & & 0.30 & 0.26 \\
\hline 102 & C8-Cyclohexane & & 0.043 & 0.074 \\
\hline 5 & $\begin{array}{l}\text { Cyclobutane, 1,2-diethyl-, } \\
\text { trans- \& cis- }\end{array}$ & & 0.15 & 0.27 \\
\hline 59 & Cyclododecane & $294-62-2$ & 1.3 & 0.2 \\
\hline 17 & Cyclohexane, 1-methyl-3-propyl- & $4291-80-9$ & 0.20 & 0.17 \\
\hline 19 & Cyclohexane, (3-methyl-pentyl)- & $61142-38-9$ & 0.11 & 0.19 \\
\hline 20 & $\begin{array}{l}\text { Cyclohexane, 1,5-diethyl- } \\
\text { 2,3-dimethyl- }\end{array}$ & $74663-66-4$ & 0.095 & 0.165 \\
\hline 24 & Cyclohexane, (1-methyipropyl)- & $7058-01-7$ & 0.24 & 0.06 \\
\hline 69 & $\begin{array}{l}\text { Cyclohexane, 2-butyl-1, } \\
\text { 1,3-trimethyl- }\end{array}$ & $54676-39-0$ & 1.7 & 0.2 \\
\hline 72 & Cyclohexane, (4-methylpentyi)- & $61142-20-9$ & 0.84 & 0.06 \\
\hline 88 & $\begin{array}{l}\text { Cyclooctane, 1-methylpropyl- } \\
\text { and others }\end{array}$ & & 0.14 & 0.12 \\
\hline 89 & Cyclooctane, butyl- & $16538-93-5$ & 0.055 & 0.096 \\
\hline 6 & Cyclopropane, propyl- & $2415-72-7$ & 0.11 & 0.19 \\
\hline 39 & Cyclopropane, octyl- & $1472-09-9$ & 0.62 & 0.12 \\
\hline 68 & Cycopentane, 1-pentyl-2-propyl- & $62199-51-3$ & 0.078 & 0.135 \\
\hline 26 & Decane, 5-methyl- & $13151-35-4$ & 0.44 & 0.04 \\
\hline 27 & Decane, 4-methyl- & $2847-72-5$ & 0.34 & 0.08 \\
\hline 28 & Decane, 2-methyl- & $6975-98-0$ & 1.0 & 0.2 \\
\hline 30 & Decane, 3-methyl- & $13151-34-3$ & 0.53 & 0.03 \\
\hline 86 & Decane, 6-ethyl-2-methyl- & $62108-21-8$ & 0.37 & 0.63 \\
\hline
\end{tabular}




\begin{tabular}{|c|c|c|c|c|}
\hline Cmpd & Compound & $\begin{array}{l}\text { CAS }^{1} \\
\text { Number }\end{array}$ & $\begin{array}{l}\text { Average } \\
\left(\mathrm{mg} / \mathrm{m}^{3}\right)\end{array}$ & $\begin{array}{c}\text { Standard } \\
\text { Deviation } \\
\left(\mathrm{mg} / \mathrm{m}^{3}\right) \\
\end{array}$ \\
\hline 65 & $\begin{array}{l}\text { Dimethyl-decahydro naphthalene } \\
\text { + others }\end{array}$ & 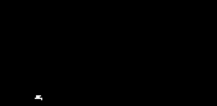 & 0.31 & 0.27 \\
\hline 116 & Dimethyl-naphthalene & & 0.17 & 0.29 \\
\hline 73 & Dodecane, 4-methyl- & $6117-97-1$ & 0.78 & 0.06 \\
\hline 74 & Dodecane, 2-methyl- & $1560-97-0$ & 1.5 & 0.1 \\
\hline 76 & Dodecane, 4,6-dimethyl- & $61141-72-8$ & 3.8 & 0.4 \\
\hline 96 & Dodecane, 3-methyl- & $17312-57-1$ & 0.29 & 0.51 \\
\hline 100 & Dodecane, 2,7,10-trimethyl- & $74645-98 m 0$ & 2.6 & 0.2 \\
\hline 112 & Dodecane, 2,6,11-trimethyl- & $31295-56-4$ & 0.055 & 0.096 \\
\hline 118 & Dodecane, 2-methyl-8-propyl- & $55045-07-3$ & 0.45 & 0.78 \\
\hline 3 & Furan, tetrahydro- & $109-99-9$ & 0.89 & 0.79 \\
\hline 8 & Heptanal & $111-71-7$ & 0.10 & 0.17 \\
\hline 84 & Heptane, 3-ethyl-5-methyl- & $52896-90-9$ & 0.19 & 0.33 \\
\hline 101 & Heptane, 2-phenyl- & $2132-84-5$ & 0.24 & 0.27 \\
\hline 114 & Hexadecane & $544-76-3$ & 0.56 & 0.07 \\
\hline 1 & Methane, trichlorofluoro- & $75-69-4$ & 0.51 & 0.88 \\
\hline 50 & Methyldecahydronaphthalene & & 3.1 & 0.5 \\
\hline 45 & Mixture & & 0.11 & 0.20 \\
\hline 29 & Naphthalene, decahydro-, trans- & $493-02-7$ & 0.53 & 0.10 \\
\hline 41 & Naphthalene, decahydro-2-methyi- & $2958-76-1$ & 0.39 & 0.54 \\
\hline 60 & Naphthalene, decahydro-1,2-dimethyl- & $3604-14-6$ & 0.71 & 0.18 \\
\hline 14 & Nonane, 4-methyl- & $17301-94-9$ & 0.12 & 0.20 \\
\hline 21 & Nonane, 2,6-dimethyl- & $17302-28-2$ & 1.1 & 0.2 \\
\hline 119 & Pentadecane, 2-methyl- & $1560-93-6$ & 0.056 & 0.096 \\
\hline 122 & Pentadecane & $629-62-9$ & 0.77 & 0.63 \\
\hline 10 & Styrene & $100-42-5$ & 0.11 & 0.19 \\
\hline 104 & Tetradecane & $62 \theta-59-4$ & 4.5 & 1.8 \\
\hline 95 & Tridecane, 4-methyl- & $26730-12-1$ & 0.51 & 0.11 \\
\hline 97 & Tridecane, 2-methyl- & $1560-96-9$ & 0.70 & 0.22 \\
\hline
\end{tabular}




\begin{tabular}{|c|c|c|c|c|}
\hline$\underset{\#}{\text { Cimpd }}$ & Compound & $\begin{array}{l}\text { CAS }^{1} \\
\text { Number }\end{array}$ & $\begin{array}{l}\text { Average } \\
\left(\mathrm{mg} / \mathrm{m}^{3}\right)\end{array}$ & $\begin{array}{c}\text { Standard } \\
\text { Deviation } \\
\left(\mathrm{mg} / \mathrm{m}^{3}\right)\end{array}$ \\
\hline 105 & Tridecane, 4,8-dimethyl- & $55030-62-1$ & 0.29 & 0.51 \\
\hline 110 & Tridecane, 4-methyl- & $26730-12-1$ & 0.087 & 0.151 \\
\hline 113 & Tridecane, 4,8-dimethyl- & $55030-62-1$ & 0.047 & 0.081 \\
\hline 79 & Trimethyldecahydronaphthalene & & 0.48 & 0.09 \\
\hline 40 & Undecane, 5-methyl- & $1632-70-8$ & 0.82 & 0.19 \\
\hline 42 & Undecane, 2,8-dimethyl- & $17301-25-6$ & 0.097 & 0.168 \\
\hline 43 & Undecane, 4,8-dimethyl- & $17301-33-6$ & 0.083 & 0.143 \\
\hline 44 & Undecane, 3,8-dimethyl- & $17301-30-3$ & 2.0 & 0.7 \\
\hline 52 & Undecane, 4-methyl- & $2980-69-0$ & 1.1 & 0.4 \\
\hline 53 & Undecane, 2-methyl- & $7045-71-8$ & 2.3 & 1.1 \\
\hline 55 & Undecane, 3-methyl- & $1002-43-3$ & 1.2 & 0.6 \\
\hline 57 & Undecane, 3-methyl- & $1002-43-3$ & 0.16 & 0.28 \\
\hline 62 & Undecane, 2,4-dimethyl- & $17312-80-0$ & 0.046 & 0.079 \\
\hline 63 & Undecane, 2,6-dimethyl- & $17301-23-4$ & 3.4 & 0.2 \\
\hline 64 & Undecane, 4,7-dimethyl- & $17301-32-5$ & 0.43 & 0.05 \\
\hline 67 & Undecane, 2,10-dimethyl- \& others & & 0.14 & 0.24 \\
\hline 70 & Undecane, 5-ethyl- & $17453-94-0$ & 0.19 & 0.05 \\
\hline 82 & Undecane, 3,8-dimethyl- & $17301-30-3$ & 0.055 & 0.096 \\
\hline 87 & Undecane, 5-ethyl- & $17453-94-0$ & 0.48 & 0.45 \\
\hline 9 & Xylene & $1330-20-7$ & 0.40 & 0.39 \\
\hline 11 & Xylene & $1330-20-7$ & 0.12 & 0.21 \\
\hline \multicolumn{2}{|c|}{ Sum of tentatively identified compounds: } & & 67.03 & \\
\hline
\end{tabular}

$1 \mathrm{CAS}=$ Chemical Abstract Service. 
Table 4-11

Tank C-102 Tentatively Identified Organic Compounds in TST Samples

Sorted by Estimated Concentation -Analyses by Oak Ridge National Laboratory

\begin{tabular}{|c|c|c|c|c|}
\hline $\begin{array}{c}\text { Cmpd } \\
\#\end{array}$ & Compound & $\mathrm{CAS}^{1}$ Number & $\begin{array}{l}\text { Average } \\
\left(\mathrm{mg} / \mathrm{m}^{3}\right)\end{array}$ & $\begin{array}{c}\text { Standard } \\
\text { Deviation } \\
\left(\mathrm{mg} / \mathrm{m}^{3}\right)\end{array}$ \\
\hline 104 & Tetradecane & $629-59-4$ & 4.5 & 1.8 \\
\hline 76 & Dodecane, 4,6-dimethyl- & $61141-72-8$ & 3.8 & 0.4 \\
\hline 63 & Undecane, 2,6-dimethyl- & $17301-23-4$ & 3.4 & 0.2 \\
\hline 50 & Methyldecahydronaphthalene & & 3.1 & 0.5 \\
\hline 100 & Dodecane, $2,7,10$-trimethyl- & $74645-98-0$ & 2.6 & 0.2 \\
\hline 53 & Undecane, 2-methyl- & $7045-71-8$ & 2.3 & 1.1 \\
\hline 44 & Undecane, 3,8-dimethyl- & $17301-30-3$ & 2.0 & 0.7 \\
\hline 51 & 6-Methylundecane & $17302-33-9$ & 1.8 & 1.3 \\
\hline 69 & $\begin{array}{l}\text { Cyclohexane, 2-butyl-1, } \\
\text { 1,3-trimethyl- }\end{array}$ & $54676-39-0$ & 1.7 & 0.2 \\
\hline 74 & Dodecane, 2-methyl- & $1560-97-0$ & 1.5 & 0.1 \\
\hline 59 & Cyclododecane & $294-62-2$ & 1.3 & 0.2 \\
\hline 55 & Undecane, 3-methyl- & $1002-43-3$ & 1.2 & 0.6 \\
\hline 49 & 3-Undecene, 2-methyl-, (Z)- & $74630-48-1$ & 1.1 & 1.7 \\
\hline 81 & 6-Tridecane, 7-methyl- & $24949-42-6$ & 1.1 & 0.1 \\
\hline 15 & 3-Buten-2-ol & $598-32-3$ & 1.1 & 0.48 \\
\hline 52 & Undecane, 4-methyl- & $2980-69-0$ & 1.1 & 0.4 \\
\hline 21 & Nonane, 2,6-dimethyl- & $17302-28-2$ & 1.1 & 0.2 \\
\hline 28 & Decane, 2-methyl- & $6975-98-0$ & 1.0 & 0.2 \\
\hline 35 & 2-Nonanone & $821-55-6$ & 1.0 & 0.1 \\
\hline 56 & 4-Undecene, 4-methyl- & $61142-40-3$ & 0.99 & 0.64 \\
\hline 94 & C7-Cyclohexane & & 0.93 & 0.06 \\
\hline 106 & $1,1^{\prime}$-biphenyl & $92-52-4$ & 0.92 & 0.86 \\
\hline 3 & Furan, tetrahydro & $109-99-9$ & 0.89 & 0.79 \\
\hline 72 & Cyclohexane, (4-methylpentyl)- & $61142-20-9$ & 0.84 & 0.06 \\
\hline 12 & C8-Alkanone & & 0.82 & 0.34 \\
\hline
\end{tabular}




\begin{tabular}{|c|c|c|c|c|}
\hline $\begin{array}{c}\text { Cmpd } \\
\#\end{array}$ & Compound & $\mathrm{CAS}^{1}$ Number & $\begin{array}{l}\text { Average } \\
\left(\mathrm{mg} / \mathrm{m}^{3}\right)\end{array}$ & $\begin{array}{c}\text { Standard } \\
\text { Deviation } \\
\left(\mathrm{mg} / \mathrm{m}^{3}\right)\end{array}$ \\
\hline 40 & Undecane, 5-methyl- & $1632-70-8$ & 0.82 & 0.19 \\
\hline 73 & Dödecane, 4-methyi- & $6117-97-1$ & 0.78 & 0.06 \\
\hline 122 & Pentadecane & $629-62-9$ & 0.77 & 0.63 \\
\hline 60 & Naphthalene, decahydro-1,2-dimethyl- & $3604-14-6$ & 0.71 & 0.18 \\
\hline 97 & Tridecane, 2-methyl- & $1560-96-9$ & 0.70 & 0.22 \\
\hline 39 & Cyclopropane, octyl- & $1472-09-9$ & 0.62 & 0.12 \\
\hline 114 & Hexadecane & $544-76-3$ & 0.56 & 0.07 \\
\hline 2 & 2-Butanone & $78-93-3$ & 0.55 & 0.95 \\
\hline 29 & Naphthalene, decahydro-, trans- & $493-02-7$ & 0.53 & 0.10 \\
\hline 30 & Decane, 3-methyl- & $13151-34-3$ & 0.53 & 0.03 \\
\hline 1 & Methane, trichlorofluoro- & $75-69-4$ & 0.51 & 0.88 \\
\hline 95 & Tridecane, 4-methyl- & $26730-12-1$ & 0.51 & 0.11 \\
\hline 108 & 1,1-Biphenyl,2-methyl- & $643-58-3$ & 0.48 & 0.57 \\
\hline 87 & Undecane, 5-ethyl- & $17453-94-0$ & 0.48 & 0.45 \\
\hline 77 & $\begin{array}{l}\text { 2-Butenoic acid, } \\
\text { 2-propenyl ester \& others }\end{array}$ & & 0.27 & 0.48 \\
\hline 79 & Trimethyldecahydronaphthalene & & 0.48 & 0.09 \\
\hline 54 & Benzene, pentyl- & $538-68-1$ & 0.46 & 0.48 \\
\hline 118 & Dodecane, 2-methyl-8-propyl- & $55045-07-3$ & 0.45 & 0.78 \\
\hline 34 & 5-Undecene & $4941-53-1$ & 0.44 & 0.01 \\
\hline 26 & Decane, 5-methyl- & $13151-35-4$ & 0.44 & 0.04 \\
\hline 64 & Undecane, 4,7-dimethyl- & $17301-32-5$ & 0.43 & 0.05 \\
\hline 92 & C8-cyclohexane & & 0.41 & 0.29 \\
\hline 38 & 1-Undecene, 4-methyl- & $74630-39-0$ & 0.41 & 0.36 \\
\hline 9 & Xylene & $1330-20-7$ & 0.40 & 0.39 \\
\hline 41 & Naphthalene, decahydro-2-methyl- & $2958-76-1$ & 0.39 & 0.54 \\
\hline 86 & Decane, 6-ethyl-2-methyl- & $62108-21-8$ & 0.37 & 0.63 \\
\hline 103 & 3-Dodecanone & $1534-27-6$ & 0.35 & 0.12 \\
\hline 27. & Decane, 4-methyl- & $2847-72-5$ & 0.34 & 0.08 \\
\hline
\end{tabular}




\begin{tabular}{|c|c|c|c|c|}
\hline Cmpd & Compound & CAS $^{1}$ Number & $\begin{array}{l}\text { Average } \\
\left(\mathrm{mg} / \mathrm{m}^{3}\right)\end{array}$ & $\begin{array}{c}\text { Standard } \\
\text { Deviation } \\
\left(\mathrm{mg} / \mathrm{m}^{3}\right)\end{array}$ \\
\hline 93 & C14-alkene & & 0.32 & 0.14 \\
\hline 61 & 4-Dodecene, (E)- & $7206-15-7$ & 0.30 & 0.12 \\
\hline 98 & C8-Cyclohexene & & 0.30 & 0.26 \\
\hline 25 & 1,1-dimethyl-2-propylcyclohexane & & 0.30 & 0.03 \\
\hline 96 & Dodecane, 3-methyl- & $17312-57-1$ & 0.29 & 0.51 \\
\hline 105 & Tridecane, 4,8-dimethyl- & $55030-62-1$ & 0.29 & 0.51 \\
\hline 65 & $\begin{array}{l}\text { Dimethyl-decahydro naphthalene } \\
+ \text { others }\end{array}$ & & 0.31 & 0.27 \\
\hline 5 & $\begin{array}{l}\text { Cyclobutane, 1,2-diethyl-, } \\
\text { trans- \& cis- }\end{array}$ & . & 0.15 & 0.27 \\
\hline 71 & 3-Hexadecyne & $61886-62-2$ & 0.25 & 0.01 \\
\hline 58 & C13-Alkane & & 0.25 & 0.43 \\
\hline 24 & Cyciohexane, (1-methylpropyl)- & $7058-01-7$ & 0.24 & 0.06 \\
\hline 101 & Heptane, 2-phenyl- & $2132-84-5$ & 0.24 & 0.27 \\
\hline 4 & $2(3 \mathrm{H})$-furanone, dihydro-3,5-dimethyl- & $5145-01-7$ & 0.24 & 0.22 \\
\hline 126 & Benzenesulfonamide, $\mathrm{N}$-butyl- & $3622-84-2$ & 0.23 & 0.04 \\
\hline 109 & $\begin{array}{l}\text { Benzene, } 1,1^{\prime} \text {-methylenebis- } \\
\text { and others }\end{array}$ & & 0.24 & 0.22 \\
\hline 13 & 1,1,2,3-tetramethylcyclohexane & $6783-92-2$ & 0.22 & 0.20 \\
\hline 121 & 3-Tridecanone & $1534-26-5$ & 0.21 & 0.14 \\
\hline 22 & Benzene, 1-propenyi- & $637-50-3$ & 0.21 & 0.18 \\
\hline 17 & Cyclohexane, 1-methyl-3-propyl- & $4291-80-9$ & 0.20 & 0.17 \\
\hline 84 & Heptane, 3-ethyl-5-methyl- & $52896-90-9$ & 0.19 & 0.33 \\
\hline 91 & C12-alkene and C7-benzene & & 0.19 & 0.16 \\
\hline 70 & Undecane, 5-ethyl- & $17453-94-0$ & 0.19 & 0.05 \\
\hline 37 & 5-Undecene, (E)- & $764-97-6$ & 0.18 & 0.32 \\
\hline 116 & Dimethyl-naphthalene & & 0.17 & 0.29 \\
\hline 75 & $\begin{array}{l}\text { 2-Hexanone, 3-cyclo- } \\
\text { hexyliden-4-ethyl- }\end{array}$ & & 0.18 & 0.16 \\
\hline 57 & Undecane, 3-methyl- & $1002-43-3$ & 0.16 & 0.28 \\
\hline
\end{tabular}


WHC-SD-WM-ER-459 Rev.1

\begin{tabular}{|c|c|c|c|c|}
\hline$\underset{\#}{\text { Cmpd }}$ & Compound & CAS ${ }^{1}$ Number & $\begin{array}{l}\text { Average } \\
\left(\mathrm{mg} / \mathrm{m}^{3}\right)\end{array}$ & $\begin{array}{c}\text { Standard } \\
\text { Deviation } \\
\left(\mathrm{mg} / \mathrm{m}^{3}\right)\end{array}$ \\
\hline 83 & Alkane & & 0.16 & 0.16 \\
\hline 78 & Benzene, (1-methylpentyl)- & $6031-02-3$ & 0.15 & 0.26 \\
\hline 120 & 5-Undecanone, 2-methyl- & $50639-02-6$ & 0.15 & 0.26 \\
\hline 67 & Undecane, 2,10-dimethyl- \& others & & 0.14 & 0.24 \\
\hline 33 & C4-benzene \& others & & 0.14 & 0.24 \\
\hline 31 & Benzene, 1-methyl-2-propyl- & $1074-17-5$ & 0.14 & 0.25 \\
\hline 18 & 2-Decene, (E)- & $20063-97-2$ & 0.14 & 0.13 \\
\hline 47 & 1-Dodecene & $112-41-4$ & 0.14 & 0.13 \\
\hline 80 & 3-Undecanone & $2216-87-7$ & 0.13 & 0.23 \\
\hline 32 & 4-Nonanone & $4485-09-0$ & 0.13 & 0.23 \\
\hline 99 & 5-Undecanone, 2-methyl- & $50639-02-6$ & 0.13 & 0.22 \\
\hline 11 & Xylene & $1330-20-7$ & .0 .12 & 0.21 \\
\hline 88 & $\begin{array}{l}\text { Cyclooctane, 1-methylpropyl- } \\
\text { and others }\end{array}$ & & 0.14 & 0.12 \\
\hline 14 & Nonane, 4-methyl- & $17301-94-9$ & 0.12 & 0.20 \\
\hline 48 & 5-Undecene, 7-methyl- (E)- & $74630-66-3$ & 0.12 & 0.21 \\
\hline 10 & Styrene & $100-42-5$ & 0.11 & 0.19 \\
\hline 6 & Cyclopropane, propyl- & $2415-72-7$ & 0.11 & 0.19 \\
\hline 19 & Cyclohexane, (3-methyl-pentyl)- & $61142-38-9$ & 0.11 & 0.19 \\
\hline 45 & Mixture & & 0.11 & 0.20 \\
\hline 36 & 2-Decene, 4-methyl-, (Z) & $74630-30-1$ & 0.11 & 0.19 \\
\hline 8 & Heptanal & $111-71-7$ & 0.10 & 0.17 \\
\hline 23 & 4,5-Nonadiene & $821-74-9$ & 0.10 & 0.17 \\
\hline 85 & Alkane & & 0.10 & 0.17 \\
\hline 46 & Benzene, (2-methyl-2-propenyl)- & $3290-53-7$ & 0.099 & 0.171 \\
\hline 42 & Undecane, 2,8-dimethyl- & $17301-25-6$ & 0.097 & 0.168 \\
\hline 90 & C4-Cyclohexane & & 0.095 & 0.165 \\
\hline 20 & $\begin{array}{l}\text { Cyclohexane, 1,5-diethyl- } \\
\text { 2,3-dimethyl }\end{array}$ & $74663-66-4$ & 0.095 & 0.165 \\
\hline
\end{tabular}




\begin{tabular}{|c|c|c|c|c|}
\hline$\underset{\#}{\text { Cmpd }}$ & Compound & $\mathrm{CAS}^{1}$ Number & $\begin{array}{l}\text { Average } \\
\left(\mathrm{mg} / \mathrm{m}^{3}\right)\end{array}$ & $\begin{array}{c}\text { Standard } \\
\text { Deviation } \\
\left(\mathrm{mg} / \mathrm{m}^{3}\right)\end{array}$ \\
\hline 7 & Benzene, ethyl- & $100-41-4$ & 0.090 & 0.155 \\
\hline 110 & Tridecane, 4-methyl- & $26730-12-1$ & 0.087 & 0.151 \\
\hline 43 & Undecane, 4,8-dimethyl- & $17301-33-6$ & 0.083 & 0.143 \\
\hline 16 & Benzene, (1-methylethyl)- & $98-82-8$ & 0.079 & 0.136 \\
\hline 68 & Cycopentane, 1-pentyl-2-propyl- & $62199-51-3$ & 0.078 & 0.135 \\
\hline 125 & 9H-Fluorene & $86-73-7$ & 0.077 & 0.134 \\
\hline 111 & C8-cyclohexane & & 0.068 & 0.117 \\
\hline 123 & 1,1'-Biphenyl, 2-methyl- & $643-58-3$ & 0.067 & 0.116 \\
\hline 115 & 2-Undecanone, 6, 10-dimethyl- & $105-42-0$ & 0.059 & 0.103 \\
\hline 119 & Pentadecane, 2-methyl- & $1560-93-6$ & 0.056 & 0.096 \\
\hline 89 & Cyclooctane, butyl- & $16538-93-5$ & 0.055 & 0.096 \\
\hline 112 & Dodecane, 2,6,11-trimethyl- & $31295-56-4$ & 0.055 & 0.096 \\
\hline 82 & Undecane, 3,8-dimethyl- & $17301-30-3$ & 0.055 & 0.096 \\
\hline 107 & $\begin{array}{l}\text { 2-Hexenoic acid, } \\
\text { 2-hexenyl ester, (E,E)- }\end{array}$ & $54845-28-2$ & 0.052 & 0.090 \\
\hline 113 & Tridecane, 4,8-dimethyl- & $55030-62-1$ & 0.047 & 0.081 \\
\hline 62 & Undecane, 2,4-dimethyl- & $17312-80-0$ & 0.046 & 0.079 \\
\hline 66 & 4-Undecene, 5-methyl- (Z)- & $74630-69-6$ & 0.045 & 0.077 \\
\hline 102 & C8-Cyclohexane & & 0.043 & $\cdot 0.074$ \\
\hline 124 & 1,1'-Biphenyl, 2-methyl- & $643-58-3$ & 0.039 & 0.067 \\
\hline 117 & Benzene, (1-methylheptyl)- & $777-22-0$ & 0.031 & 0.053 \\
\hline \multicolumn{3}{|c|}{ Sum of tentatively identified compounds: } & 67.03 & \\
\hline
\end{tabular}

$1 \mathrm{CAS}=$ Chemical Abstract Service. 

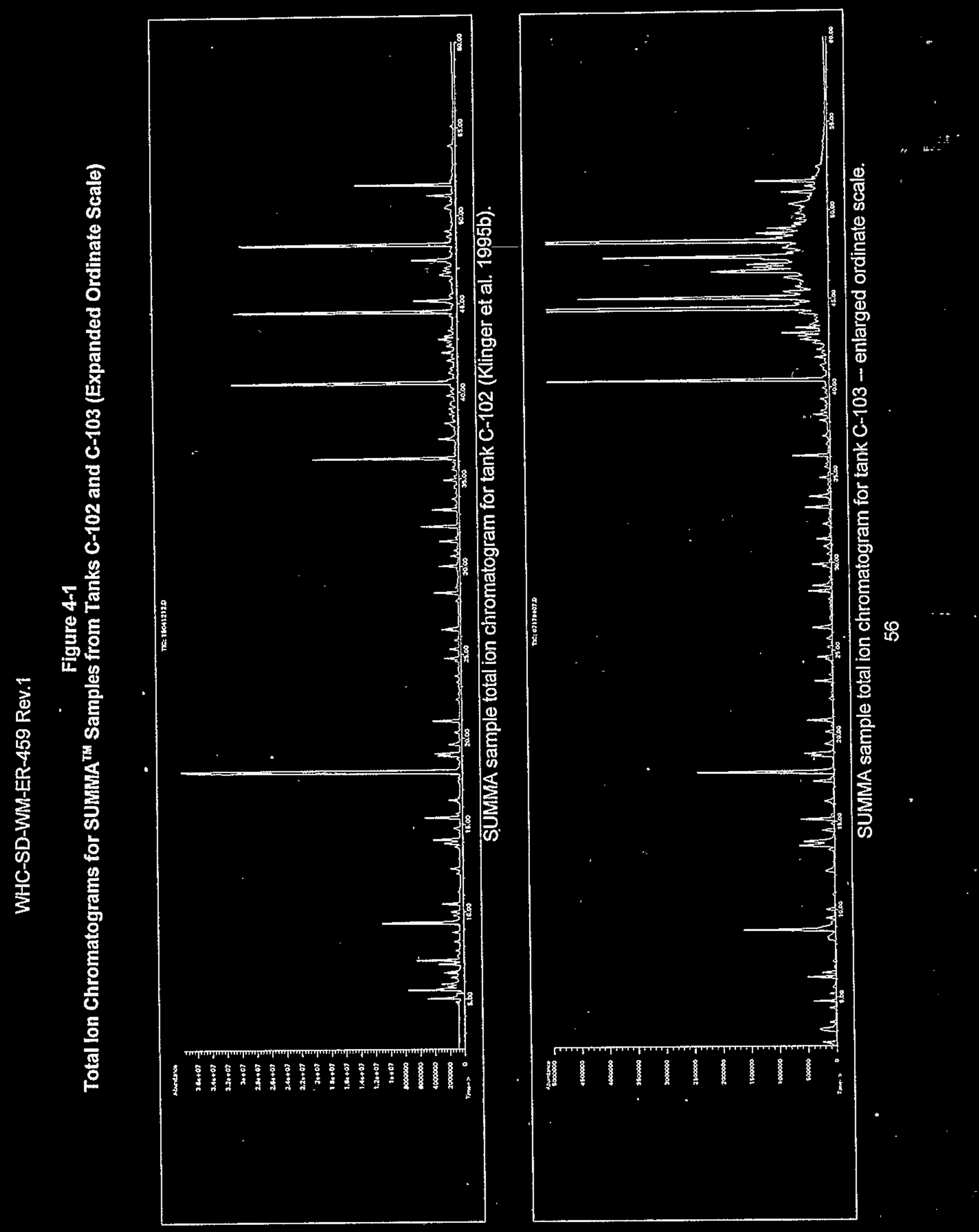

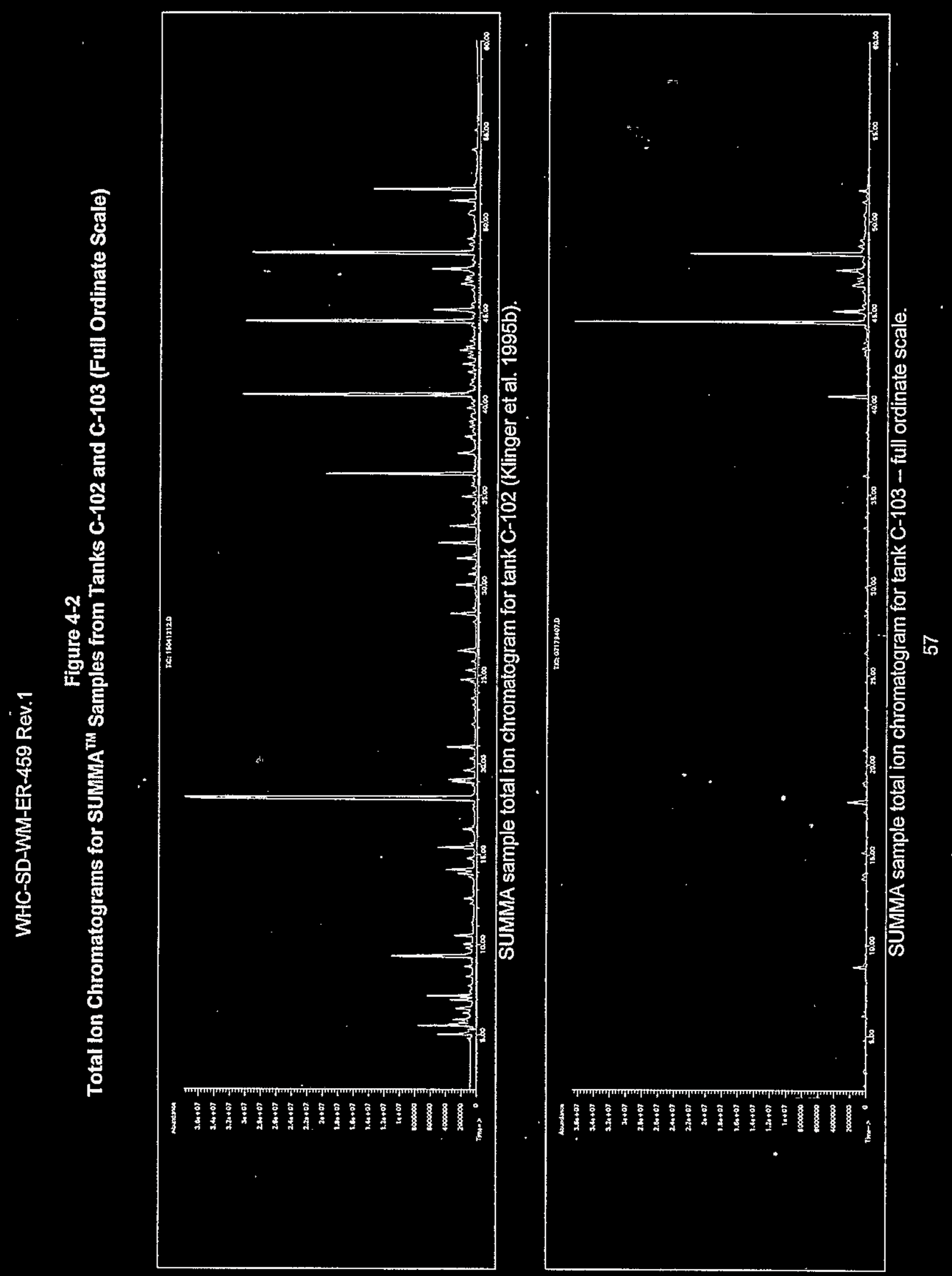


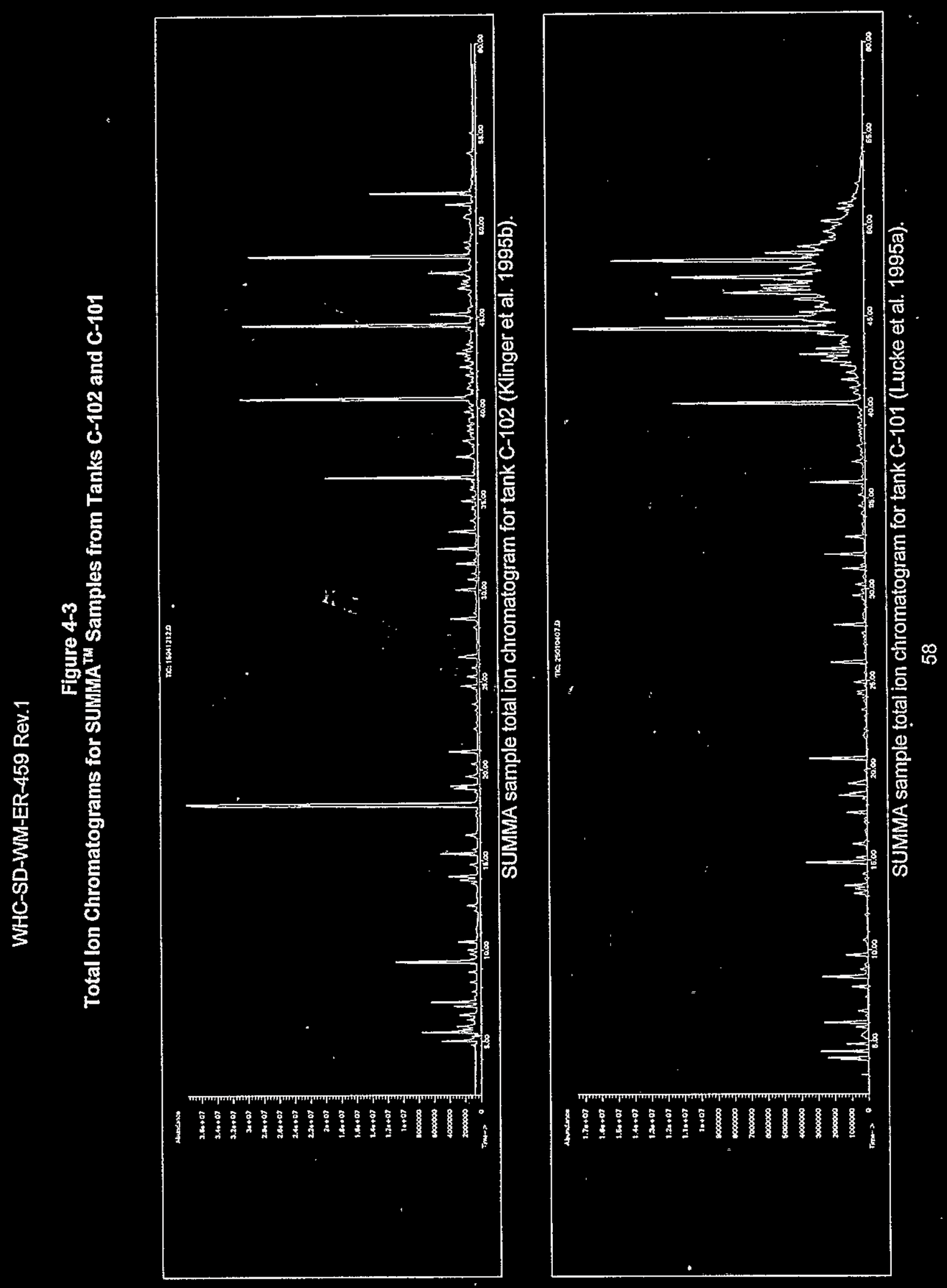


